\title{
Requirement for Protein Synthesis at Developing Synapses
}

\author{
Joseph Sebeo, ${ }^{1}$ Kuangfu Hsiao, ${ }^{1 \star}$ Ozlem Bozdagi, ${ }^{1 \star}$ Dani Dumitriu, ${ }^{1}$ Yongchao Ge, ${ }^{2}$ Qiang Zhou, ${ }^{2}$ \\ and Deanna L. Benson ${ }^{1}$ \\ ${ }^{1}$ Fishberg Department of Neuroscience and ${ }^{2}$ Department of Neurology, Mount Sinai School of Medicine, New York, New York 10029
}

Activity and protein synthesis act cooperatively to generate persistent changes in synaptic responses. This forms the basis for enduring memory in adults. Activity also shapes neural circuits developmentally, but whether protein synthesis plays a congruent function in this process is poorly understood. Here, we show that brief periods of global or local protein synthesis inhibition decrease the synaptic vesicles available for fusion and increase synapse elimination. $\mathrm{Ca}^{2+} / \mathrm{calmodulin}$-dependent protein 1 se II (CaMKII) is a critical target; its levels are controlled by rapid turnover, and blocking its activity or knocking it down rapitula s the effects of protein synthesis inhibition. Mature presynaptic terminals show decreased sensitivity to protein syntb sis hibitio, and resistance coincides with a developmental switch in regulation from CaMKII to PKA (protein kinase A). These f ding den strate a novel mechanism regulating presynaptic activity and synapse elimination during development, and suggest that t a traslation acts coordinately with activity to selectively stabilize appropriate synaptic interactions.

\section{Introduction}

Synaptic activity and new protein synthesis collaborate in learning of new tasks, in the formation of long-lasting men ories, and in the generation of persistent changes in responses (Linden, 1994; Steward and Worley, 2001 Abr ham and Williams, 2003). During development, levels and at activity can also influence synaptogenesis in the amma on CNS by accelerating maturation, promoting rete on prow king elimination of synapses (Katz and Shat 1996; W liky, 2000; Sanes and Lichtman, 2001; Lanuza et 1., 20 2; Personius and Balice-Gordon, 2002; De Paola et al., 20 ? ohen al., 2006; Yao et al., 2006). Comparatively little $\mathrm{Kr}$ wn $\mathrm{w}$ the role of protein synthesis in synaptogenes

During development, proten synthesis levels peak during synaptogenesis (Phillips et al., 1990), quggesting that young synapses have a particularly high demand for new proteins. High levels of synthesis in part provide the raw materials needed to generate and differentiate new synapses. Consistent with this, long-term exposure to protein synthesis inhibitors can inhibit synapse assembly in invertebrate neurons (Schacher and $\mathrm{Wu}$, 2002; Meems et al., 2003). But more recent work has demonstrated that sustained suppression of a particular mRNA encoding the peptide, sensorin, can also inhibit synaptogenesis (Lyles et al., 2006), suggesting that protein synthesis contributes a more specific and regulated role. Such targeted protein synthesis could

Received June 4, 2009; accepted June 15, 2009.

This work was supported by National Institutes of Health (NIH) Grants NS37731 and NS050634 and NIH Predoctoral Fellowship F30NS056610. We thank Dr. S. Vincini and A. K. McAllister for providing CDNA constructs. We thank Dr. Cristina Alberini, Dr. George W. Huntley, Dr. Kira Poskanzer, and Dr. Robert Blitzer for their advice and comments on this manuscript, and Jenny Cho, Roxana Mesias, and Bill Janssen for technical support.

*K.H. and O.B. contributed equally to this work.

Correspondence should be addressed to Deanna L. Benson, Fishberg Department of Neuroscience, Mount Sinai School of Medicine, 1425 Madison Avenue, Box 1065, New York, NY 10029. E-mail: deanna.benson@mssm.edu.

Q. Zhou's present address: One DNA Way, Mail Stop 230 B, South San Francisco, CA 94080-4990.

DOI:10.1523/JNEUROSCI.2613-09.2009

Copyright $\odot 2009$ Society for Neuroscience $\quad$ 0270-6474/09/299778-16\$15.00/0 urve to

ounterbalance targeted protein degradation via the proteasome system, which is known to regulate synanse activity and stability (Willeumier et al., 2006; Ding et al., 2007; Yao et al., 2007).

In this study, we investigated whether protein synthesis contributes dynamically during development to synapse function and stability. We show that young presynaptic terminals and small terminals at all ages depend on a continuous supply of new proteins, and in particular on $\mathrm{Ca}^{2+} /$ calmodulin-dependent protein kinase II $\alpha$ (CaMKII $\alpha)$. Brief periods of protein synthesis inhibition, CaMKII inhibition, or CaMKII $\alpha$ knockdown, reduce the pool of synaptic vesicles available for release and increase synapse elimination. As synapses mature, the impact of protein synthesis inhibition and the role of CaMKII diminish, and the actions of protein kinase A (PKA) predominate. Our findings demonstrate that protein translation can dynamically and locally regulate presynaptic activity and synapse stability. When coupled to recent work demonstrating that regulated protein degradation can influence synapse stability (Willeumier et al., 2006; Ding et al., 2007; Yao et al., 2007), the data suggest that developing synapses ride a tightly regulated balance that can be easily tipped toward stability or instability by increasing synthesis or degradation. Several developmental diseases producing mental retardation and autism-related behaviors likely result from impaired formation of neural circuitry (Li et al., 2001; Zoghbi, 2003; Dictenberg et al., 2008; Kelleher and Bear, 2008; Walsh et al., 2008; Yashiro et al., 2009). That some can be caused by defects in proteins regulating synthesis or degradation suggests that synapse stabilization may be a particularly vulnerable stage of development.

\section{Materials and Methods}

Dissociated hippocampal neuron culture. Hippocampi were dissected from embryonic day 18 Sprague Dawley rat brains and prepared as previously described by Banker and colleagues (Goslin et al., 1998). In brief, neurons were dissociated with $0.25 \%$ trypsin for $15 \mathrm{~min}$ at $37^{\circ} \mathrm{C}$ and 
triturated through a fire-polished Pasteur pipette. Cells were then plated on $1 \mathrm{mg} / \mathrm{ml}$ poly-L-lysine-coated glass coverslips and maintained in Neurobasal medium with B-27 supplements (Invitrogen) (Zhang and Benson, 2001). Experiments were performed in cultures between 5-7 d in vitro (div) and $18-21$ div.

Antibodies. The following primary antibodies were used: anti-synapsin Ia [mouse monoclonal IgG1; immunocytochemistry (IC), 1:250; Western blotting (WB), 1:1000; Synaptic Systems], anti-p-site-3 synapsin I (rabbit polyclonal; WB, 1:1000; Invitrogen), anti-p-site-1 synapsin I (rabbit polyclonal; WB, 1:1000; Affinity Bioreagents), anti-synaptic vesicle 2 (SV2) [mouse monoclonal IgG1; Developmental Studies Hybridoma Bank (Feany et al., 1992)], anti-CaMKII $\alpha$ (rabbit polyclonal; WB, 1:2000; Millipore Bioscience Research Reagents), anti-CaMKII $\alpha$ (mouse monoclonal; IC, 1:250; Millipore), anti-CaMKI (rabbit polyclonal; WB, 1:1000; Abcam), anti-p-CaMKII ${ }_{\text {thr286 }}$ (rabbit polyclonal antibody; WB, 1:1000; Cell Signaling), anti-actin (mouse monoclonal IgG1; WB, 1:1000; Millipore Bioscience Research Reagents), anti-synaptophysin (purified Ig fraction of rabbit serum; IC, 1:5000; Zymed; or G95 at 1:5000; gift from P. DeCamilli, Yale University, New Haven, CT), anti-panShank (mouse monoclonal IgG1; IC, 1:500; NeuroMab), anti-PSD95 family (mouse monoclonal 6G6; 1:1000; Affinity Bioreagents), anitNMDAR1 (mouse monoclonal clone 54.1; gift from J. H. Morrison, Mount Sinai School of Medicine, New York, NY), anti-glyceraldehyde-3phosphate dehydrogenase (GAPDH) (rabbit polyclonal; 1:1000; Trevigen). Fluorescence-tagged secondary antibodies were obtained from Vector Laboratories and Jackson ImmunoResearch. For WB, species-appropriate horseradish peroxidase-conjugated secondary antibodies (GE Healthcare) were used.

Metabolic labeling. Anisomycin (aniso) and cycloheximide (cyclo) are commonly used to inhibit protein synthesis in neurons. Both agents block peptide elongation, but whereas aniso blocks the peptidyl transferase reaction, cyclo blocks the translocation reaction on riboson (Alberts et al., 2002). To determine the timing and degree to whic protein synthesis is inhibited by aniso or cyclo, and the m concentrations for each drug in our dissociated hippocap we measured $\left[{ }^{35} \mathrm{~S}\right]$ methionine incorporation in 7 div thionine (PerkinElmer) was added to neurons at a fir S] thionine (PerkinElmer) was added to neurons at a fir concen tion of
$3.4 \mathrm{mCi} / \mathrm{ml}$, together with vehicle (DMSO), aniso, or cy . The concentrations tested spanned 2 orders of magnitude miso, 3-30 um/0.8-80 $\mu \mathrm{g} / \mathrm{ml}$; cyclo, $7-700 \mu \mathrm{M} / 2-200 \mu \mathrm{g} / \mathrm{ml}$ ) and $4 \mathrm{re} \mathrm{ba} / \mathrm{d}$ on concentrations used in past studies (Kleiman et al., 1993; A o et al 2002; Schacher and Wu, 2002; Ghirardi et al., 2004) vo on healthy as assessed by their appearance using derent 1 interu ence contrast (DIC) microscopy (absence of blebbing, la somarswelling) for up to $8 \mathrm{~h}$. After $10 \mathrm{~min}, 30 \mathrm{~min}, 2 \mathrm{~h}, 5 \mathrm{~h}$, or $8 \mathrm{~h}$ ex sure to aniso or cyclo, neurons were washed and lysed, and protein synthesis was evaluated by scintillation counting (Kleiman et al., 1993).

We noticed a large decrease $(>50 \%)$ in $\left[{ }^{35} \mathrm{~S}\right]$ methionine incorporation at $10 \mathrm{~min}$ (supplemental Fig. 1b, available at www.jneurosci.org as supplemental material), and the decrease is more pronounced at $2 \mathrm{~h}$ (>75\%) (supplemental Fig. 1c, available at www.jneurosci.org as supplemental material) and $5 \mathrm{~h}(>86 \%)$ (supplemental Fig. $1 d$, available at www.jneurosci.org as supplemental material). Thus, new protein synthesis (and our ability to detect significant inhibition) is rapid, but well within the normal range. For mRNAs on polyribosomes, new proteins are generated on a timescale of $20 \mathrm{~s}$ to several minutes (Alberts et al., 2002).

Based on these studies, we decided to use the lowest concentrations of aniso $(8 \mu \mathrm{g} / \mathrm{ml})$ and cyclo $(20 \mu \mathrm{g} / \mathrm{ml})$ that produced maximal inhibition of $\left[{ }^{35} \mathrm{~S}\right]$ methionine incorporation. These data corroborate a previous study showing that $20 \mu \mathrm{g} / \mathrm{ml}$ cyclo blocks new protein synthesis in $14 \mathrm{div}$ neurons as monitored by $\left[{ }^{3} \mathrm{H}\right]$ leucine uptake in the absence of cell death for up to $12 \mathrm{~h}$. This study also showed that neurons remained metabolically active (Kleiman et al., 1993).

Immunocytochemistry. Neurons were fixed using 4\% paraformaldehyde with $4 \%$ sucrose in PBS and permeabilized with $0.25 \%$ Triton $\mathrm{X}-100$. Nonspecific binding was blocked by preincubation in $10 \% \mathrm{BSA}$, and neurons were incubated in primary antibodies (diluted in 1\% BSA) at $4^{\circ} \mathrm{C}$ overnight. This was followed by incubation with speciesappropriate secondary antibodies for $2 \mathrm{~h}$.

Microscopy. Single optical sections were acquired using a Zeiss LSM 510 confocal microscope, a $63 \times$ objective [numerical aperture (NA) 1.3] at a resolution of $512 \times 512$; cluster area and fluorescence intensity were quantified using MetaMorph (Molecular Devices) (Zhang and Benson, 2006). To assess appositions, images were acquired using a $100 \times$ objective (NA 1.3) at a resolution of $1024 \times 1024$. Labeled regions were defined by thresholding, and appositions were defined as sites measuring at least $200 \mathrm{~nm}$ in diameter having overlap or contact.

FM dye recycling. Styryl dyes have been used extensively to study synaptic vesicle recycling (Betz et al., 1992), including in dissociated hippocampal cultured neurons (Ryan et al., 1993; Klingauf et al., 1998). All imaging experiments were performed at $36.5^{\circ} \mathrm{C}, 5 \% \mathrm{CO}_{2}$ in imaging media containing the following (in $\mathrm{mM}$ ): $124 \mathrm{NaCl}, 3 \mathrm{KCl}, 2 \mathrm{CaCl}_{2}, 1.25$ $\mathrm{NaH}_{2} \mathrm{PO}_{4}, 2 \mathrm{MgSO}_{4}, 10$ dextrose, $26 \mathrm{NaHCO}_{3}, \mathrm{pH}$ 7.35. Images were acquired using a $40 \times$ objective (NA 1.3) on a Zeiss LSM510 confocal microscope. After $2 \mathrm{~h}$ control (vehicle) treatment, neurons were labeled with FM4-64 (Invitrogen; $10 \mu \mathrm{M}$ ) by depolarizing with imaging media containing $60 \mathrm{~mm} \mathrm{KCl}$ and $27 \mathrm{~mm} \mathrm{NaCl}$, as well as $10 \mu \mathrm{M}$ DNQX (SigmaAldrich) and $50 \mu \mathrm{M}$ APY o1g Aldrich) to block recurrent excitation. After an extensive wa FM dyc vas then unloaded using stimulating media in the absen of The netics of FM dye release was assessed by taking $50 \mathrm{im}$, es over 14 , fter washout, the same cell was treated for $2 \mathrm{~h}$ with a cyclo; $\mathrm{M}$ dye was then reloaded into the same neuron ay an lhe ge w taken, followed by FM dye release kinetics assessm In some oriments, aniso or cyclo was washed out, rons were allo red to recover for $4 \mathrm{~h}$, and FM dye uptake and release were a cessed again. 1 is allowed a comparison of vesicle recycling at the same tes after ontrol, aniso or cyclo treatment, and washout. All data were alyzed $y$ ing MetaMorph and exported into Excel for analysis. Statistica parisons were made using Excel or Prism. To examine FM dye take as a function of FM dye site area, data were exported and graphed in Excel using a scatter plot, and a logarithmic best-fit curve was added. To label the readily releasable pool (RRP), neurons were stimulated by application of hypertonic sucrose (500 mM) (Rosenmund and Stevens, 1996).

For post hoc immunolabeling, after FM uptake and release, neurons were fixed using $4 \%$ paraformaldehyde with $4 \%$ sucrose in PBS for 10 min and permeabilized with $0.25 \%$ Triton X-100 for $1 \mathrm{~min}$ followed by washes. Nonspecific binding was blocked by preincubation in $10 \%$ BSA for $30 \mathrm{~min}$, and neurons were incubated in primary antibodies (diluted in $1 \%$ BSA) for $1 \mathrm{~h}$. This was followed by incubation with speciesappropriate secondary antibodies for $30 \mathrm{~min}$.

Electrophysiological recordings. For assessing postsynaptic activity, cultured hippocampal neurons on coverslips were placed in a custom-made recording chamber on the stage of an Olympus BX51W and perfused at a rate of $1-2 \mathrm{ml} / \mathrm{min}$ with artificial CSF (ACSF) containing the following (in mM): $127 \mathrm{NaCl}, 2.5 \mathrm{KCl}, 1.25 \mathrm{NaH}_{2} \mathrm{PO}_{4}, 25 \mathrm{NaHCO}_{3}, 25$ D-glucose, 2 $\mathrm{CaCl}_{2}$, and $1 \mathrm{MgCl}_{2}$. To record EPSCs, the recording pipettes were filled with the following (in $\mathrm{mm}$ ): $125 \mathrm{CsMeSO}_{4}, 10$ tetraethylammonium, 5 $\mathrm{NaCl}, 10$ HEPES ( $\mathrm{Na}^{+}$salt), 4 lidocaine, 1.1 EGTA, $4 \mathrm{ATP}\left(\mathrm{Mg}^{2+}\right.$ salt $)$, and $0.3 \mathrm{GTP}\left(\mathrm{Na}^{+}\right.$salt $)$. Neurons were held at $-70 \mathrm{mV}$ under voltage clamp. Picrotoxin $(50 \mu \mathrm{M})$ was added in ACSF to inhibit $\mathrm{GABA}_{\mathrm{A}}$ receptor-mediated response. To record action potentials, $\mathrm{K}^{+}$-based internal solution was used (in mm: 128 potassium gluconate, $10 \mathrm{NaCl}, 10$ HEPES, 0.5 EGTA, $2 \mathrm{MgCl}_{2}$, $4 \mathrm{Na}_{2} \mathrm{ATP}, 0.4 \mathrm{NaGTP}$ ). All recording were performed at room temperature. EPSCs were analyzed using MiniAnalysis (Synaptosoft) and action potentials were analyzed with Clampfit (Molecular Devices).

For long-term potentiation (LTP) experiments, hippocampal slices $(350 \mu \mathrm{m})$ were taken from postnatal day 6 (P6) Sprague Dawley rats using a McIllwain tissue chopper. Slices were perfused continuously with Ringer's solution containing the following (in $\mathrm{mM}$ ): $125.0 \mathrm{NaCl}, 2.5 \mathrm{KCl}$, $1.3 \mathrm{MgSO}_{4}, 1.0 \mathrm{NaH}_{2} \mathrm{PO}_{4}, 26.2 \mathrm{NaHCO}_{3}, 2.5 \mathrm{CaCl}_{2}, 11.0$ glucose, bubbled with $95 \% \mathrm{O}_{2} / 5 \% \mathrm{CO}_{2}$, during extracellular recordings (electrode solution: $3 \mathrm{M} \mathrm{NaCl}$ ). Slices were maintained for $1-2 \mathrm{~h}$ before establishment of a baseline (20-30 min) of field EPSPs (fEPSPs). The temperature of the recording chamber was maintained at $32 \pm 1^{\circ} \mathrm{C}$ for the duration of 
the experiments. Field EPSPs were recorded from stratum radiatum in area CA1, evoked by stimulation of the Schaffer collateral-commissural afferents every $30 \mathrm{~s}$ with bipolar tungsten electrodes with $100 \mu$ s pulses. Test stimulus intensity was adjusted to obtain fEPSPs with amplitudes that were one-half of the maximal response. The EPSP initial slope (in millivolts per millisecond) was determined from the average waveform of four consecutive responses. Data were digitized at $10 \mathrm{kHz}$ through a Digidata 1200 interface controlled by pClamp software (Molecular Devices). LTP was induced with four trains of $100 \mathrm{~Hz}, 1 \mathrm{~s}$ tetanic stimulation separated by $5 \mathrm{~min}$ and recorded for $20 \mathrm{~min}$ after tetanus. Input-output curves were obtained by plotting the stimulus voltages against the slopes of EPSPs. Slices were incubated in aniso (bath-applied; $20 \mu \mathrm{M}$ ), starting from $20 \mathrm{~min}$ before tetanic stimulation and continued until the end of recordings.

Western blotting. Changes in levels and phosphorylation states of endogenous proteins were assessed by Western blots as previously described (Mintz et al., 2003). Hippocampal cells were homogenized in SDS Laemmli sample buffer and total protein concentration was determined by using a Bradford assay and a BioSpec 1601 spectrophotometer. Equal protein amounts were fractionated on a $7.5 \%$ SDS-polyacrylamide gel before transfer to polyvinylidene difluoride paper. Blots were blocked and probed with primary antibody overnight. Species-appropriate horseradish peroxidase-conjugated secondary antibodies (GE Healthcare) were added for $1 \mathrm{~h}$, and after washes, label was visualized with SuperSignal ECL (Pierce). Films were developed using an SRX-101 Tabletop Processor (Konica Photo Imaging). Films were scanned and then quantified using MetaMorph.

Transfections and live imaging. Neurons were transfected at the time of plating with green fluorescent protein (GFP)-synapsin I (gift from P. Greengard, Rockefeller University, New York, NY, and S. Vincini, Georgetown University Medical Center, Washington, DC) using the Amaxa Nucleoporator. With this method, efficiency is typically $50-8{ }^{m}$ and for many neurons the level of expression is within about two tim endogenous protein levels (assessed by immunocytochemistru lished work supports that, within this range, these exogenous unlikely to alter the progression of synapse formatio (Bresler et al., 2001; Renger et al., 2001; Graf et al 2004). veurons, immersed in imaging media described above, we raged ( $D$ and fluorescence) using the $40 \times$ objective (NA 1.3) n a Zeis 'SM510 confocal microscope, after exposure to veh fe or proten synthesis inhibitors.

Local protein synthesis inhibition. To annly $\mathrm{P}$ cein sy thesis inhibitors locally, we used an approach describ « pr ious, bohof et al. (1992) to generate local guidance cue grac nts. ics) was used to eject aniso $(80 \mu \mathrm{g} / \mathrm{m}$, rom pipettes with a tip diameter of $\sim 1 \mu \mathrm{m}$, for $200 \mathrm{~ms}$ every $10 \mathrm{~s}$, for $45 \mathrm{~m}$. Based on data from Lohof et al. (1992), a total volume of about $\sim 4 \mathrm{pl}$ was delivered into a bath volume of $2.5 \mathrm{ml}$, making the bath an infinite sink that does not accumulate an effective drug concentration. Lucifer yellow ( $50 \mu \mathrm{M}$; Invitrogen) was included in the pipettes with aniso to visualize at the end of the experiment the area affected by aniso. DIC images were also taken at the beginning and end of the experiments to assess neuron health. Experiments were performed on a Nikon Diaphot300, and images were taken using a Hamamatsu ORCA ER camera.

Pharmacological manipulations. CaMKI/II activity was inhibited using $N$-[2-[N-(4-chlorocinnamyl)- $N$-methylaminomethyl] phenyl]- $N$-(2hydroxyethyl)-4-methoxybenzenesulfonamide phosphate salt (KN93) (Hook and Means, 2001; Shi and Ethell, 2006) (10 $\mu \mathrm{M}$; Sigma-Aldrich) applied for 1 h. 2-[N-(4-Methoxybenzenesulfonyl)] amino- $N$-(4chlorphenyl)- $N$-methylbenzylamine phosphate (KN92) (10 $\mu \mathrm{M}$; SigmaAldrich), an inactive analog of KN93, was used as negative control. The selective CAMK kinase (CaMKK) antagonist 7-oxo-7H-benzimidazo[2, 1-a]benz[de] isoquinolone-3-carboxylic acid (STO-609) (Sigma-Aldrich; $2.5 \mu \mathrm{M}$ ) was also used as previously described and characterized in hippocampal neurons (Wayman et al., 2004). The cAMP analog adenosine 3',5'-cyclic monophosphorothioate, $\mathrm{Rp}$ isomer (Rp-cAMPS) (100 $\mu \mathrm{M}$; BioLog Life Science Institute), applied for $1 \mathrm{~h}$, was used as a PKA inhibitor. The stearated cell-permeable Ht31 peptide (St-Ht31) (50 $\mu \mathrm{M}$; Promega) was used to inhibit interactions between PKARII and
A-kinase-anchoring protein (AKAP). The Ht31 peptide contains an amphipathic helical domain, similar to that used by all known AKAPs to bind to RII subunits. It acts as a competitive inhibitor (Carr et al., 1992a). Stearated, membrane-permeable, versions of the peptide have been characterized and used in a wide variety of cell types (Vijayaraghavan et al., 1997; Oliveria et al., 2007), including dissociated hippocampal neurons (Snyder et al., 2005). A second stearated peptide (St-Ht31P) (50 $\mu \mathrm{M}$; Promega) that has two isoleucines in $\mathrm{Ht} 31$ replaced with prolines and does not bind RII was used as a control. The mechanism by which stearated peptides gain entry into neurons has not been determined, but they are thought to intercalate with and be retained at the plasmalemma (Carr et al., 1992b; Kole et al., 1996; Klussmann et al., 1999). The stearated moieties did not appear to contribute nonspecifically to the outcomes observed in the current study as St-Ht31p had no detectable effect on synaptic vesicle recycling. To inhibit proteasome-mediated degradation, neurons were treated with the cell-permeable irreversible proteasome inhibitor clasto-lactacystin $\beta$-lactone (Dick et al., 1996) (10 $\mu \mathrm{M}$ in DMSO; Sigma-Aldrich).

Small interfering RNA- and short hairpin RNA-mediated knockdown. CAMKII $\alpha$ was knocked down using two different approaches. In the first $100 \mathrm{~nm}$ of a pool of four nterfering RNAs (siRNAs) targeting rat CaMKII $\alpha$ (Accell siRY SMAR ool; Thermo Scientific Dharmacon). Accell siRNAs are annea 7 , dsRN, oligos with 3'-UU overhangs, a 5' -P on the antisense and (Elb hi tal., 2001), and have been modified for efficient uptak $n$th absence of transfection reagents. The SMARTpool is a group fou RNA that have been screened to reduce a variety of pote loff-ta effects including the inclusion of miRNA (microkNA) ike seed motifs and the possibility that the sense strand will b canen into th RNA-induced silencing complex (Lin et al., 2005; Biringham t al., 2006). Having four siRNAs reduces the effective concenation of ach individual siRNA, further reducing the potential for offta. ef cts (Jackson et al., 2003; Semizarov et al., 2003; Echeverri and arrimon, 2006). As a positive control, we assessed knockdown of GArDH using Accell rat GAPD control pool (four siRNAs), and as a negative control, we used a nontargeting Accell pool consisting of four siRNAs, each of which contains at least four mismatches to any human, mouse, or rat gene and has been microarray tested. In the second, four different short hairpin RNAs (shRNAs) targeting CaMKII $\alpha$ and a control shRNA were obtained from SABiosciences. The shRNAs were expressed under a U1 promoter and a GFP reporter, under a CMV promoter from the same vector. Neurons were transfected using the AMAXA electroporator, mixed in a 2:1 ratio with untransfected neurons, and analyzed after 7 div. Effectiveness of the shRNA knockdown was assessed by Western blot, and shRNA1 was found to be most effective (supplemental Fig. 8, available at www.jneurosci.org as supplemental material).

Statistical analysis. Data were exported to Excel or Prism and differences between groups were assessed using Student's $t$ test for two groups or ANOVA for three or more groups followed by Bonferonni's post-tests. Numbers and specific tests are indicated in the figure legends.

\section{Results}

\section{Translation inhibition reduces synaptic vesicle recycling}

We used an FM dye (FM4-64) to label presynaptic terminals so that we could track location and monitor function of the same terminals over several hours. Using the protocol outlined in Figure 1a, 1-week-old cultured hippocampal neurons were exposed to imaging media for $2 \mathrm{~h}$, and presynaptic terminals were then loaded with FM4-64, by stimulating neurons with $60 \mathrm{mM} \mathrm{KCl}$ for 2 min (Betz et al., 1996; Harata et al., 2001). Numerous sites, heterogeneous in size, decorated the cell bodies and dendrites of neurons (Fig. 1b). Neurons were then stimulated again for $2 \mathrm{~min}$ in the absence of dye, and an image was taken (Fig. 1b). As expected, nearly all labeling was lost as dye-filled vesicles fuse with the membrane.

Aniso was then added for $2 \mathrm{~h}$ (a time chosen based on outcomes observed in pilot studies that covered a range from 1 to $24 \mathrm{~h}$ ) after which terminals on the same neuron were reloaded 


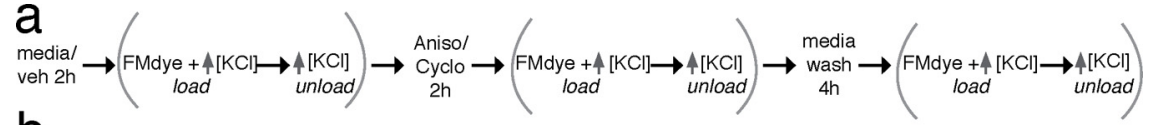

b

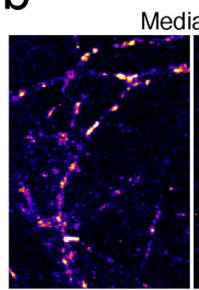

Media + veh

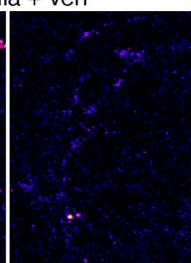

unload

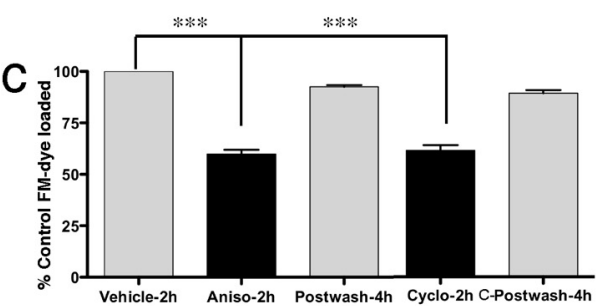

d

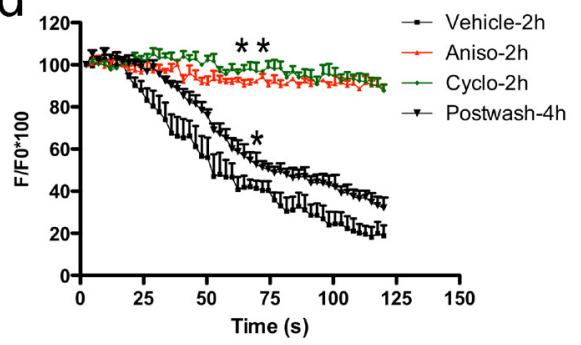

Aniso 2h

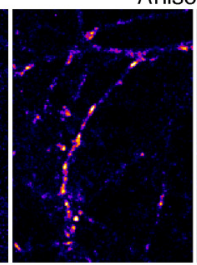

load
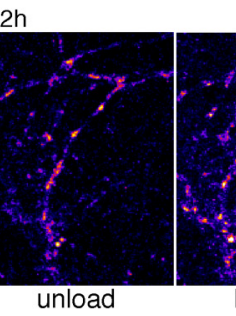

Postwash 4h

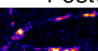

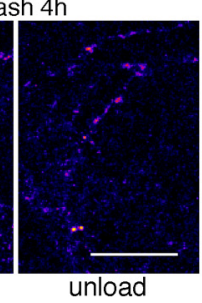

load (n)

Fig. 1, available at www.jneurosci.org as supplemental material) (Raff et al., 1993; Cano et al., 1994; Zinck et al., 1995; Alberini, 2008). Cyclo treatment yielded outcomes indistinguishable from aniso (Fig. 1c). Thus, protein synthesis inhibition alters synaptic vesicle recycling.

To understand the relationship between protein synthesis and vesicle recycling in greater detail, we measured the kinetics of vesicle release after dye loading by acquiring images every $2 \mathrm{~s}$ while stimulating neurons with high $\mathrm{KCl}$ in the absence of dye. FM dye release was almost completely prevented in young neurons exposed to either aniso or cyclo (Fig. 1d), but $4 \mathrm{~h}$ after washout, vesicle recycling showed a near-complete recovery (Fig. The retention of dye during unloading cou led to the decreased intensity afer upt ke suggest that the predominant en of protein synthesis inhibition on presynaptic terminals is to reduce the umber of vesicles available to fuse with the membrane.

\section{Postsynaptic function unaltered by protein synthesis inhibition}

Protein synthesis inhibition impairs presynaptic function, but it may be that this occurs in response to the loss of postsyn-

Figure 1. Protein synthesis inhibition reduces vesicles available for exocytosi a, ane 0 proach used to track changes in FM dye uptake and release before and after exposure to protein synthesis inb itors. $\boldsymbol{b}$.onfocal lages, displayed using a lookup table in which warmer colors are most intense, illustrate the reduction in $M$ a), "ur ake anu ru ar absence of dye release (unload) that is observed in young neurons exposed to aniso for $2 \mathrm{~h}$ relative to shicle (veh, M/SO) control. Four hours after washout, dye intensity after loading is similar to vehicle, and release values ap,roach ontrol levers. $\mathrm{c}$, Bar graph plots the change in FM dye fluorescence intensity after $2 \mathrm{~h}$ aniso, $2 \mathrm{~h}$ cyclo, or a $4 \mathrm{~h}$ washo' period relatic vehicle control. Both aniso and cyclo significantly decrease FM dye intensity after loading. Recovery is com ce after vashout. $d$, The change in fluorescence intensity as FM dye is exocytosed from synaptic vesicles in response to stimulat is otted oy $120 \mathrm{~s}$ after $2 \mathrm{~h}$ vehicle (black), and then $2 \mathrm{~h}$ aniso (red) or cyclo (green), and $4 \mathrm{~h}$ after aniso washout (blas' $\rightarrow \mathrm{m}$, ung , rons nages were taken approximately every $2 \mathrm{~s}$. Data are based on $74<n<112 \mathrm{FM}$ dye sites for each con wion (t 2 en from r least 4 neurons from 2 separate cultures). Groups in c were

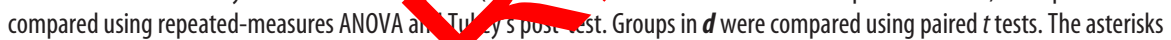
represent statistical significance with respect to ntrol: ${ }^{*} p<0.05 ;{ }^{* *} p<0.001 ;{ }^{* * *} p<0.0001$. DIC images of neurons exposed to the same treatment paradigms are shown in supplemental Figure 2 (available at www.jneurosci.org as supplemental material). Error bars indicate SEM. Scale bar, $19 \mu \mathrm{m}$.

with FM dye (Fig. 1b,c; supplemental Fig. 1, available at www. jneurosci.org as supplemental material). The overall pattern of labeled terminals was similar to what was observed before aniso, but intensity was decreased by $40 \%$ (Fig. 1b,c). Even more striking, when neurons were stimulated in the absence of dye, intensity decreased only modestly and the dye appeared trapped in most terminals (Fig. 1b).

To ensure that these changes were not simply attributable to diminished health or a rundown in activity over time, we asked whether FM dye loading recovers after washout of the inhibitor. Four hours after washout, intensity of FM dyeloaded terminals returned to control values (Fig. $1 b$,c; supplemental Fig. 2, available at www.jneurosci.org as supplemental material).

Aniso rapidly inhibits new protein synthesis, but it can also have additional, unrelated effects (Alberini, 2008). To address this, we performed a parallel set of experiments using cyclo, which blocks translation by a different mechanism (supplemental aptic function. To assess postsynaptic function, we performed whole-cell patchclamp recordings in the presence of TTX in young neurons that had been exposed to vehicle or aniso for $2 \mathrm{~h}$. Consistent with previous work, the overall level of synaptic activity was low (Gomperts et al., 2000; Mozhayeva et al., 2002), but the amplitude of miniature EPSCs (mEPSCs) was similar in vehicle and aniso-treated neurons (Fig. 2a). mEPSC frequency was also similar, suggesting that the readily releasable pool of docked synaptic vesicles is preserved (Mozhayeva et al., 2002). The consistent amplitude indicates that postsynaptic receptors are present on the surface, functional, and not detectably altered by protein synthesis inhibition.

Since FM dye experiments showed that protein synthesis inhibition decreased the available vesicle pool, postsynaptic responses after higher frequency stimulation would be expected to be reduced by protein synthesis inhibition. To test this, we recorded spontaneous currents under voltage clamp $\left(V_{\mathrm{h}}=-70 \mathrm{mV}\right)$ in the absence of TTX in neurons exposed to either aniso or vehicle. In some neurons, we recorded spontaneous burst-like activity-a barrage of synaptic events within a short period of time (Fig. $2 b$ ). The duration and mean amplitude of bursting activity were markedly reduced in aniso-treated neurons, whereas the peak amplitude was similar to control neurons (Fig. 2b). These changes are consistent with a reduction in the available pool of vesicles in that presynaptic glutamate release cannot follow sustained incoming action potentials propagating through the culture network. However, they could also result from an aniso-induced decrease 
in neuronal excitability by, for example, altering sodium channel density that would prevent neurons from sustaining spiking activity. To test this, we compared neuronal excitability in neurons treated with aniso or vehicle by injecting depolarizing current and counting the number of action potentials generated. There were no differences between groups (supplemental Fig. 3, available at www.jneurosci. org as supplemental material). Together, these findings support that protein synthesis inhibition decreases the pool of vesicles available for release. They also indicate that an FM dye-mediated reduction in vesicle fusion events that can be detected with modest stimulation protocols (Zhu and Stevens, 2008) is not confounding the protein synthesis-mediated changes in vesicle availability observed here.

Stimulation protocols incorporating series of bursts such as those observed spontaneously (above) can induce LTP, and thus, our findings in culture would predict that protein synthesis inhibition would also affect the induction of LTP in young slices. In hippocampal slices taken from P6 rats, none of the slices treated with aniso showed LTP in CA1, whereas LTP was induced in $73.3 \%$ of the control slices [aniso-treated, $101.6 \pm 1.9 \%(n=13)$; control, $127.7 \pm 5.8 \%(n=15) ; 15 \mathrm{~min}$ after tetanus; $p<0.05$ ] (Fig. 3c). Basal synaptic transmission was unaffected by aniso, and no differences were found in the input-output curves obtained from control and anisotreated hippocampal slices (slopes, 0.16 $0.09, n=15$, vs $0.15 \pm 0.11, n=13$; $t$ te $p>0.5)$. These data indicate that synthesis can regulate synaptic nctio in an intact network of young synap Additionally, they underscore difference be-

tween developing and mature circuits, in which protein synthesis is dispensable for LTP induction, but essential for LTP maintenance (Frey et al., 1988; Huang et al., 1996).

\section{Translation blockade selectively impairs the recycling pool, leaving RRP intact}

Whole-cell recording experiments show normal mEPSCs after $2 \mathrm{~h}$ of protein synthesis inhibition, suggesting that the RRP is intact. To confirm this, we measured FM dye uptake stimulated by hypertonic shock (500 mM sucrose) (Rosenmund and Stevens, 1996). In control conditions (media \pm vehicle), the pool of vesicles labeled was $\sim 30 \%$ the intensity of that labeled by $\mathrm{KCl}$ stimulation (Fig. 3a). After $2 \mathrm{~h}$ aniso, sucrose stimulation yielded intensity values indistinguishable from controls (Fig. 3a). These data support that the small population of vesicles associated with the RRP can function normally after protein synthesis inhibition.

\section{Activity exacerbates the impact of protein} synthesis inhibitors

The FM dye experiments suggest that activity exacerbates the impact of protein synthesis inhibition on vesicle availability: dye

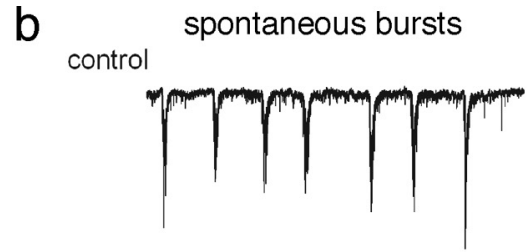

aniso
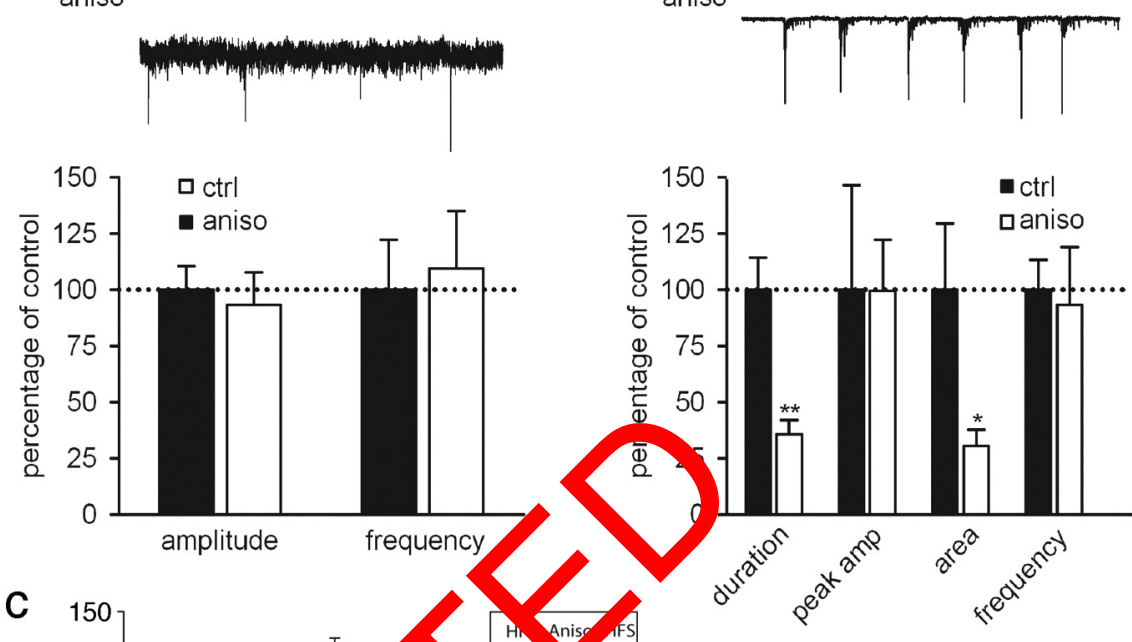

2. No fect of protein synthesis inhibition on postsynaptic activity. $\boldsymbol{a}$, Miniature EPSCs were not altered in neurons ith aniso. Is 2 PSCs were recorded from neurons treated with either vehicle or aniso for $2-4 \mathrm{~h}$ at $37^{\circ} \mathrm{C}$. Sample traces (top) montaneous vursts were reduced in neurons treated with aniso, but there was no change in the peak amplitude or frequency. $0.05 ; * * 0.01$. c, The potentiation in field EPSP slope induced by high-frequency tetanic stimulation was blocked by aniso (he period of application) in slices from P6 rats [number of animals, 9; number of slices, 15 (control) and 13 ISO); error bars indicate SD]. Inset, Representative EPSP traces were recorded before tetanus (1), 15 min after tetanus (2); before (3) and 15 min after tetanus (4) in the presence of aniso. Calibration: $10 \mathrm{~ms}, 0.2 \mathrm{mV}$. amp, Amplitude; ctrl, control.

uptake, in which we used a single round of strong stimulation to load the available vesicles, was modestly reduced, but dye release, which follows two rounds of strong stimulation (one to load and one to unload) was nearly prevented. Thus, it would be anticipated that, after exposure to protein synthesis inhibitors, a strong stimulus would disable vesicle replenishment such that few vesicles would be able to fuse and internalize dye during a second stimulus. To test this, after $2 \mathrm{~h}$ of aniso, neurons were prestimulated with high $\mathrm{KCl}$ for $2 \mathrm{~min}$ in the absence of dye, and then after 10 min, loaded with FM dye using high $\mathrm{KCl}$. Prestimulation reduced FM dye uptake after aniso relative to vehicle treatment by $>70 \%$ (vs $40 \%$ with no previous stimulation) (Fig. $3 b$ ). Four hours after washout of the inhibitor, $\mathrm{KCl}$-mediated uptake recovered to control values. Thus, the protein synthesismediated decrease in recycling vesicles is exacerbated by activity and consistent with a reduction in vesicle mobilization from a recycling pool to the releasable pool.

These findings could also be explained or accompanied by a decrease in the total number of vesicles. To address this latter possibility, we determined the size and intensity of clusters labeled for SV2, an intrinsic synaptic vesicle protein, in young neu- 
a

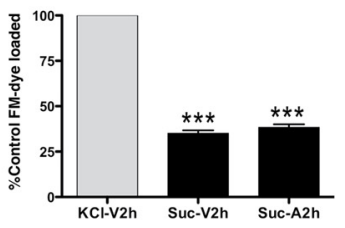

C

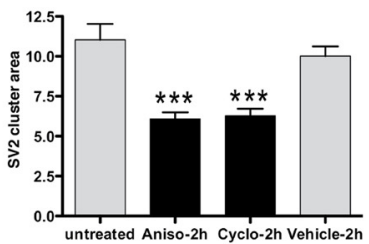

Media + veh $2 h$

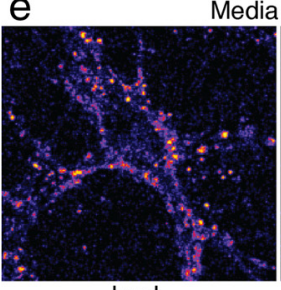

load

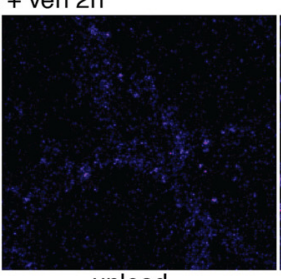

unload

$f$

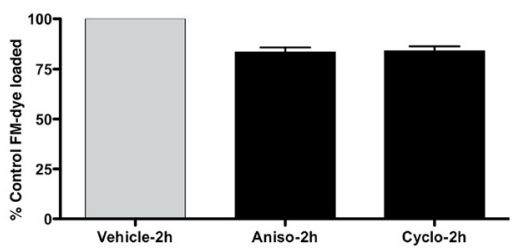
Aniso-2h

h

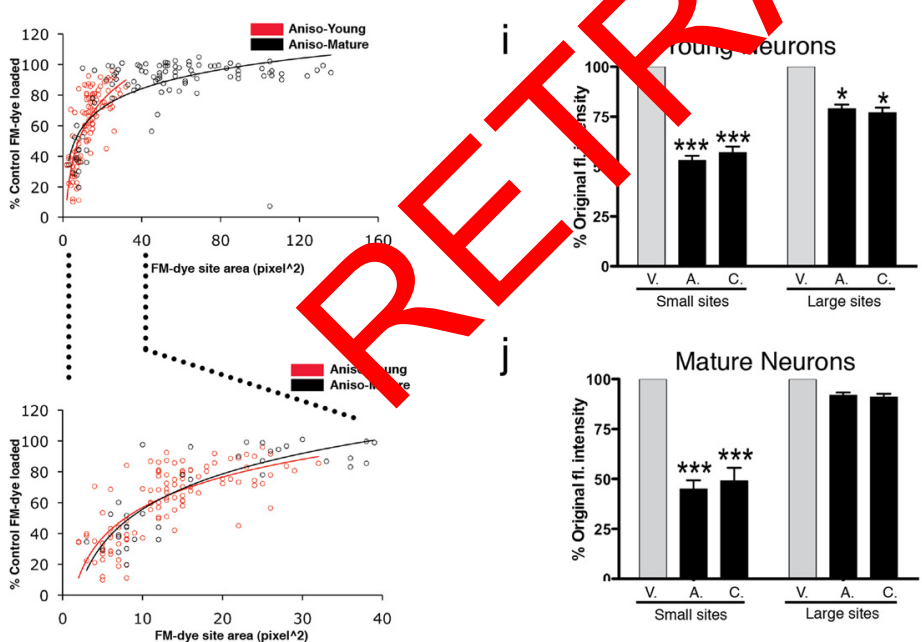

Figure 3. Translation supports vesicle recruitment during high demand in small terminals. $\boldsymbol{a}$, Bar graph plots FM dye loaded in response to hypertonic sucrose (Suc) $(500 \mathrm{~mm})$. As expected, the sucrose-loaded pool is $\sim 30 \%$ of the KCl-loaded pool. Aniso treatment does not affect uptake in this pool. A total of 151 sites was analyzed over three separate experiments. $\boldsymbol{b}$, Bar graph compares FM dye loading after vehicle or aniso treatment and two rounds of $\mathrm{KCl}$ stimulation separated by 5 min. Intensity is greatly reduced relative to vehicle and after a single round of stimulation (compare Fig. 1c). Levels recover $4 \mathrm{~h}$ after aniso washout (postwash). A total of 114 sites was analyzed over four separate experiments. $\boldsymbol{c}, \boldsymbol{d}$, Bar graphs show large and significant decreases in area (c) and intensity (d) of SV2-immunolabeled clusters in neurons that were fixed and labeled after exposure to the agents indicated (examples of the data are shown in supplemental Fig. 4, available at www.jneurosci. org as supplemental material). Data were sampled from least five neurons in each of three different cultures. $\boldsymbol{e}-\boldsymbol{g}$, Confocal images $(\boldsymbol{e})$ and graphs $(\boldsymbol{f}, \boldsymbol{g})$ show that neither FM dye loading nor the kinetics of its release are detectably altered in mature neurons after exposure to aniso or cyclo for 2 h. $\boldsymbol{h}$, Scatter plots and best-fit logarithmic curves of FM dye loaded are presented as a function of FM dye site area. FM dye-labeled terminals in young neurons treated with aniso are plotted in red, and mature, in black. The bottom plot is an expanded version of the range indicated in the top plot and shows that small terminals in young and mature neurons respond similarly to aniso. $\boldsymbol{i}, \boldsymbol{j}$, Intensity values from young $(\boldsymbol{i})$ and mature $(\boldsymbol{j})$ cultures were divided into two groups based on the distribution of site sizes in young and mature neurons. Seventy-five percent rons exposed to vehicle, aniso, or cyclo. The area and intensity of SV2 clusters were significantly reduced in response to either inhibitor $(45,38 \%$ of vehicle, respectively) with little change in overall levels (Fig. 3c,d; supplemental Fig. 4, available at www.jneurosci.org as supplemental material). Collectively, the data suggest that vesicle mobilization and pool size are both reduced by protein synthesis inhibition.

\section{Mature synapses are resistant to protein} synthesis inhibition

To determine whether the effects of protein synthesis inhibition are unique to immature synapses, we assessed the impact of aniso and cyclo on presynaptic function i - to 21-d-old (mature) neurons (Fletc $r$ et al., 1991; Papa et al., 1995; Zhang hd Benson, 2001; Mozhayeva et a. 20 2) using FM dye. In mature neurons exposed to either aniso or cyclo, FM ye loading was slightly, but insignificantly reduced relative to controls (Fig. $3 e, f)$. Release kinetics were indistinguishable from vehicle-treated controls (Fig. $3 g$ ). These data indicate that synapses on young neurons are far more vulnerable to altered levels of protein synthesis.

Generally, FM dye-labeled terminals in young neurons are smaller than those in mature neurons (Zhang and Benson, 2001; Mozhayeva et al., 2002; Mohrmann et al., 2003). With this in mind, we asked whether large FM dye sites might be more resistant to the effects of protein synthesis inhibitors, independent of the age of the neuron. We plotted the percentage change in FM dye site intensity that occurs after protein synthesis inhibition versus site area (assessed at the start of the experiment) in young and mature neurons. At both ages, below a threshold, uptake decreases progressively as sites be-

of FM dye sites in young neurons were $<15$ pixel $^{2}$, whereas only $8 \%$ of mature sites fall in this range. Thus, small sites are defined as $\leq 15$ pixel $^{2}\left(=1.35 \mu \mathrm{m}^{2}\right)$ and large as $>15$ pixel $^{2}$. Comparing these groups shows that fluorescence (fl.) intensity at small sites is significantly reduced (by $\sim 50 \%$ ) after protein synthesis inhibition (black; A., aniso; C., cyclo) relative to vehicle controls (V., vehicle) in both young (i) and mature (j) neurons. The large sites show a modest decrease in young neurons and no change in mature neurons. Groups were compared using repeated-measures ANOVA and Tukey's post-test $(\boldsymbol{a}, \boldsymbol{b}, \boldsymbol{f})$, one-way ANOVA and Bonferroni's test $(\boldsymbol{c}, \boldsymbol{d})$, or paired $t$ tests $(i, j)$. The asterisks represent statistical significance with respect to control at ${ }^{*} p<0.05,{ }^{* *} p<0.001$, and ${ }^{* * *} p<0.0001$. DIC images of neurons exposed to the same treatments are shown in supplemental Figure 2 (available at www.jneurosci.org as supplemental material). Error bars indicate SEM. Scale bar, $14.2 \mu \mathrm{m}$. 
come smaller (Fig. $3 h$ ). In fact, when the scale covering the range of small sites is expanded, the effects of protein synthesis inhibitors on both young and mature neurons can be seen to be remarkably similar (Fig. 3h). Based on the size of FM dye sites in young neurons, we separated the data into "small" and "large" sites (see legend). A comparison of these groups shows that translation inhibition substantially and significantly decreases FM dye uptake at small sites in both young and mature neurons (Fig. 3i,j). Thus, small FM dye sites, more abundant in young neurons, are particularly vulnerable to protein synthesis inhibition, whereas large sites, more abundant in mature neurons, can maintain their synaptic vesicle recycling pool independent of a continuous supply of new protein.

\section{Protein synthesis is required to maintain synapses}

Since protein synthesis inhibition reduces presynaptic function, we asked whether it might also impact synapse stability. Using the FM dye loading/unloading paradigm outlined in Figure $1 a$, we first asked whether recycling sites identified after incubation in imaging media are lost, or cease internalizing detectable amounts of FM dye (fluorescence intensity $=0$ ), after exposure to aniso. These sites were excluded from our previous analyses. Two and one-half percent of all recycling sites and $3 \%$ of small sites identified at the start of the experiment were lost after $2 \mathrm{~h}$ vehicle. In contrast, $12 \%$ of all recycling s and $>15 \%$ of small sites were lost aniso or cyclo (Fig. 4a). Four ours iter washout, $89 \%$ of the sites that we ost remained uninhabited, suggesting the the sites were truly absent and not simply below the threshold of detection. In mature neurons exposed to translation inhibitors, only small sites were lost (13\%) (Fig. 4b). These data suggest that protein synthesis inhibition either silences (Ma et al., 1999) or eliminates small presynaptic terminals in young and mature neurons.

To distinguish between these possibilities, we identified vesicle recycling sites in vehicle or aniso-treated young and mature neurons at $t=0$ and $2 \mathrm{~h}$ using FM dye, and then labeled, post hoc, for a presynaptic vesicle marker, synaptophysin (Spy), found in all presynaptic vesicles. After vehicle treatment, nearly all FM dye sites could be seen overlapping Spy-labeled clusters ( $98 \%$ in young and mature neurons) (Fig. $4 c$, yellow arrows; supplemental Fig. 5, available at www.jneurosci.org as supplemental material), and many coincided with Shank-labeled clusters (Fig. 4c). Two hours after aniso exposure, nearly all FM dye sites that were lost also lack Spy and Shank (91\% young; 97\% mature) (Fig. $4 d$, blue arrows; supplemental Fig. $5 a$, available at www.

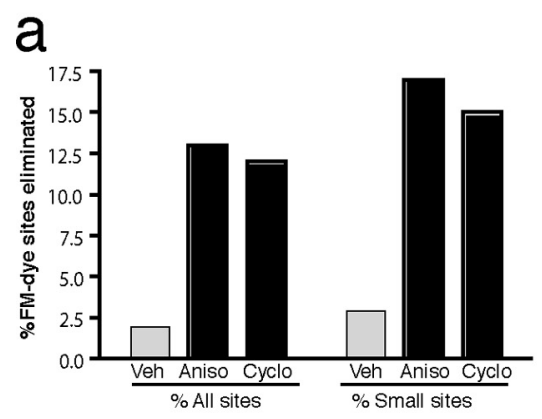

b
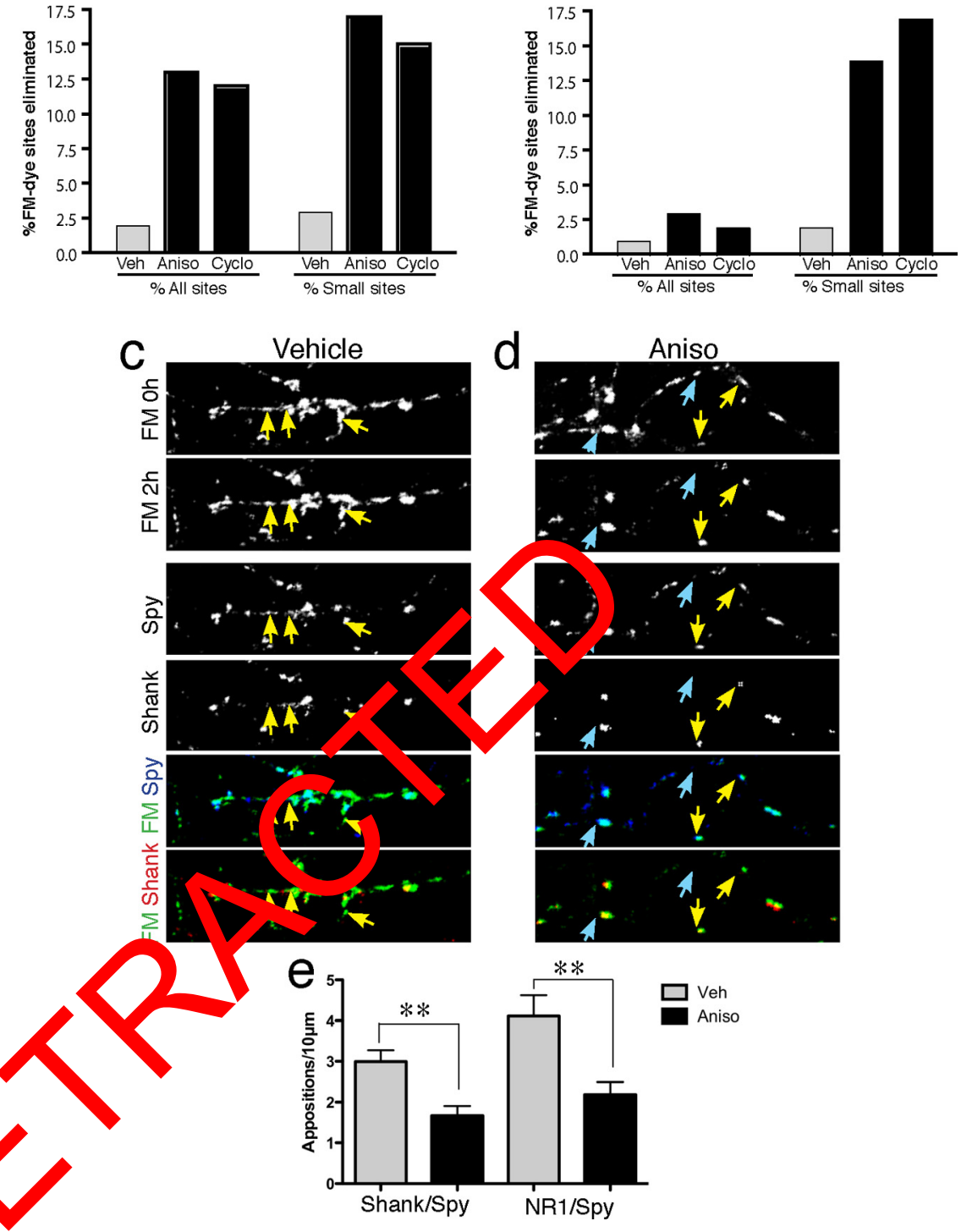

Figure 4. Protein synthesis inhibition eliminates synapses. $\boldsymbol{a}, \boldsymbol{b}$, Bar graphs show percentage FM dye sites eliminated in young (a) and mature (b) neurons after $2 \mathrm{~h}$ vehicle (Veh), $2 \mathrm{~h}$ aniso, or $2 \mathrm{~h}$ cyclo. c, $\boldsymbol{d}$, Post hoc immunostaining for FM dye sites indicates that the most stable FM dye sites are also synaptic and that sites that are lost also lack synaptic vesicle and postsynaptic markers. Terminals in vehicle-treated young neurons (c) were labeled with FM dye at 0 and $2 \mathrm{~h}$, fixed, and immunostained post hoc for Spy or Shank. There is a very high correspondence between FM dye-labeled sites (green) and Spy-labeled sites (blue). Shank (red) is not a universal marker of postsynaptic sites, but notably, it is apposed to both small (yellow arrows) and large Spy and FM dye-labeled sites. In the same paradigm, aniso-treated neurons lose FM dye sites (d). There are some sites that remain associated with Spy or Shank (yellow arrows), but FM dye sites that are lost also do not label for Spy or Shank (blue arrows). e, Quantitative analysis of the density of Shank clusters or NR1 clusters apposed to presynaptic Spy-labeled clusters along a length of dendrite (images of this and post hoc label in mature neurons in supplemental Fig. 5, available at www.jneurosci.org as supplemental material). After $2 \mathrm{~h}$ aniso treatment, there is a significant reduction in both groups. Quantification is based on data from 20 to 33 dendrites per condition taken from at least 10 different neurons in two separate cultures. Groups were compared in two-tailed unpaired $t$ tests. The asterisks represent statistical significance with respect to control at ${ }^{* *} p<0.007$. Error bars indicate SEM.

jneurosci.org as supplemental material). Thus, terminals are not silent; they are lost.

Are the terminals that are lost bona fide synapses? We restricted our analyses to FM dye-labeled sites apposing cell bodies and dendrites, but it is possible that the terminals that are lost are related to the nonsynaptic "orphan" FM dye sites observed in isolated axons (Krueger et al., 2003) or the synaptic transport vesicle clusters that have been observed to pause for up to $3 \mathrm{~min}$ before moving again in isolated axons (Sabo et al., 2006). To address 


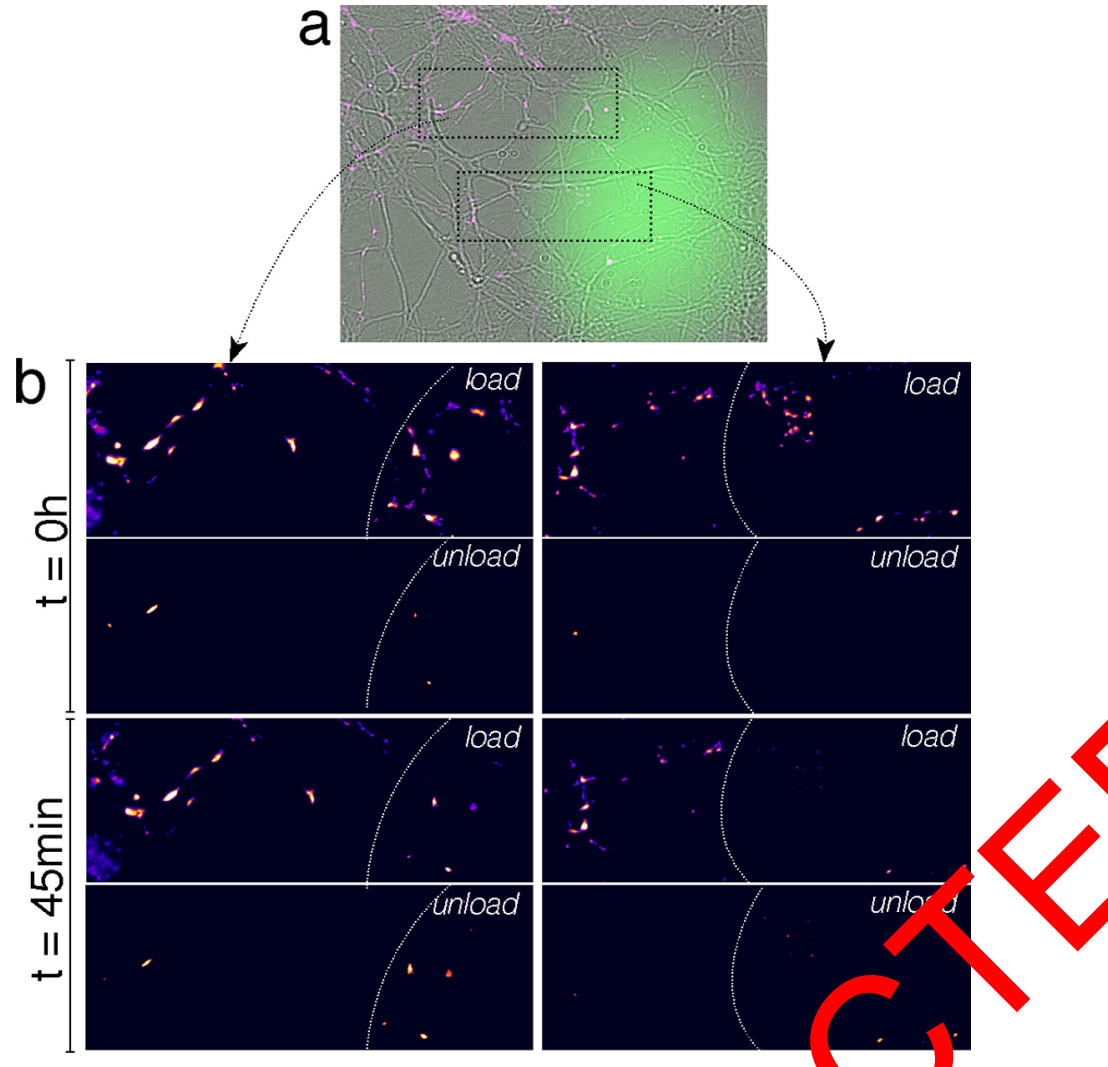

Figure 5. Local inhibition is as effective as global. $\boldsymbol{a}$, DIC image of a neuron has been ov with an in dye-labeled terminals taken at $t=0$ (magenta) and an image of the Lucifer yellow dye taken at the $\mathrm{nd} 0 \mathrm{r}$ reneriment. The dye was included in the pipette along with aniso to mark the region exposed. $\boldsymbol{b}$, Panels ored reg in $\boldsymbol{a}$ show that FM uptake and release diminish within the exposed region after $45 \mathrm{~min}$ of local aniso applicati (right fwhite yrved line), relative to $t=0$ and to sites outside the zone - including those near a cell body — which show

After 45 min, FM dye uptake was diminished significantly and release, nearly prevented within the marked zone (inside) relative to sites outside, including those near cell bodies (Fig. $5 b$ ) (percentage of FM dye intensity measured after uptake at $t=0$ at sites outside was $82.4 \pm 1 \%$, vs inside, $53.1 \pm 3 \%$; $t$ test, $p<0.0001 ; n \geq 133$ sites per group). More sites inside were eliminated (Fig. 5) (elimination outside, $5.4 \%$, vs inside, $15.2 \%$ ). Thus, local decreases in protein synthesis can regulate presynaptic function and synapse stability similar to global inhibition.

Rapid turnover makes CaMKII kinase a target for protein synthesis inhibition Protein synthesis inhibition greatly rethe pool of vesicles available for exocyt is-findings that resemble vesie rec cling defects at CNS synapses a vo synapsins or expressing mutant synapsins (Ryan et al., 1996; Menegon et 2006; Sun et al., 2006). Phosphorylation at site 3 (p-site-3; ser603) on synapsin by CaMKII dissociates synapsin I from vesicles and F-actin (Hilfiker et al., 1999). In young neurons, within $10 \mathrm{~min}$ of translation inhibition, levels of p-site-3 synapsin dropped significantly relative to total synapsin $\mathrm{I}$, which remained stable. By 2 h, levels were decreased by $80 \%$ (Fig. $6 a$ ). In parallel, CaMKII $\alpha$ levels dropped by $10 \mathrm{~min}$, and this was even more pronounced at $2 \mathrm{~h}$

these possibilities, we determined the densit of Spy-ta eled terminals apposed to clusters of a postsynaptic affold'ng protein, Shank/ ProSAP, common to many excitatory apses por NMDAR1 (NR1), the obligatory subunit of $t^{1}$ C $\mathrm{MD}$, res ptor. In neurons challenged with aniso, there wer signif cantly huwer Spy/Shank and Spy/NR1 appositions (Fig. 4e). Th, os of presynaptic to postsynaptic appositions and stable recycling 1 dye-labeled sites indicates that synapses are eliminated.

\section{Local translation inhibition similarly reduces presynaptic function}

Certain proteins can be translated locally, near sites at which they are needed, and this mechanism is essential for certain forms of synapse plasticity and synaptogenesis in invertebrates (Schacher and Wu, 2002; Lyles et al., 2006; Sutton and Schuman, 2006). Its relevance for developing mammalian synapses is unknown. We asked whether focal application of protein synthesis inhibitors would detectably reduce presynaptic function in young neurons as much as global application does. FM dye-labeled sites were identified, and a local gradient of aniso was generated over a region of dendrites and axons that was lacking cell bodies by taking advantage of a well established protocol used in growth cone turning assays over comparable time frames (Lohof et al., 1992; Zheng et al., 1994). A picospritzer was used to deliver repetitively sub-picoliter volumes of aniso along with a dye to mark the affected area into a culture volume of $2.5 \mathrm{ml}$. Outside the delivery zone, the bath acts as an infinite sink and does not accumulate an effective drug concentration (Fig. 5a) (see Materials and Methods). $(\sim 74 \%)$ (Fig. $6 b)$. Levels of phospho-CaMKII $\alpha$ (thr286; p-CaMKII $\alpha$ ), which can act independent of calcium (Miller et al., 1988; Schworer et al., 1988; Thiel et al., 1988), also decreased, but the ratio of $\mathrm{pCaMKII} \alpha / \mathrm{CaMKII} \alpha$ is maintained indicating that the decrease in pCaMKII $\alpha$ resulted from the decrease in total CaMKII $\alpha$.

Phosphorylation at site 1 (p-site-1; ser9) on synapsin I by CaMKI or PKA can also dissociate synapsin I from vesicles (Hilfiker et al., 1999). In young neurons, levels of p-site-1 synapsin and CaMKI were unchanged $10 \mathrm{~min}$ after protein synthesis blockade, but decreased significantly at 2 h $(\sim 39$ and $\sim 50 \%$, respectively) (Fig. $6 c, d$ ).

In mature neurons, levels of synapsin I, p-synapsin I (sites 1 and 3), CaMKI, CaMKII $\alpha$, and p-CaMKII $\alpha$ were unchanged after exposure to aniso or cyclo for $10 \mathrm{~min}$ or $2 \mathrm{~h}$ (supplemental Fig. 6, available at www.jneurosci.org as supplemental material), indicating that CaMKI and CaMKII $\alpha$ levels become more resistant to the effects of protein synthesis blockade.

We used immunostaining to determine where within neurons CaMKII $\alpha$ levels decrease. In untreated neurons, CaMKII $\alpha$ was distributed heterogeneously in axons (arrowheads) and dendrites (arrows), showing enhanced levels at sites with synaptophysin clusters (Fig. 6e). After $2 \mathrm{~h}$ protein synthesis inhibition, CaMKII $\alpha$ levels diminished throughout axons and dendrites, and its correlation with synaptophysin clusters decreases (Fig. $6 f$ ).

The speed with which CaMKII $\alpha$ is lost in young neurons after protein synthesis inhibition indicates that it is degraded rapidly. To assess whether it is also rapidly synthesized, we 


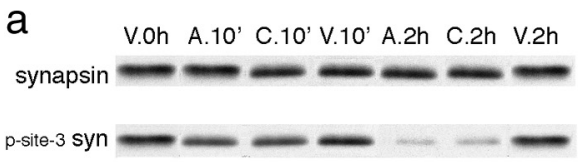

b

V.Oh A.10' C.10' V.10' A.2h C.2h V.2h

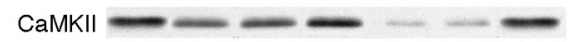

p-CaMKII $---\infty-\cdots$

C

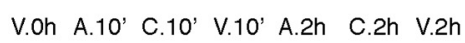

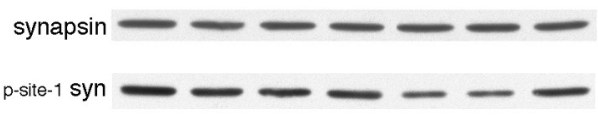

d

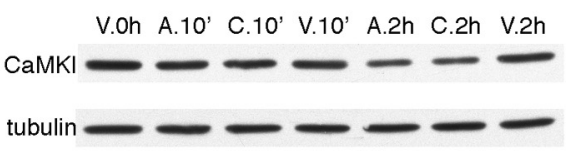

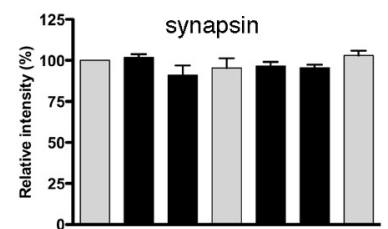
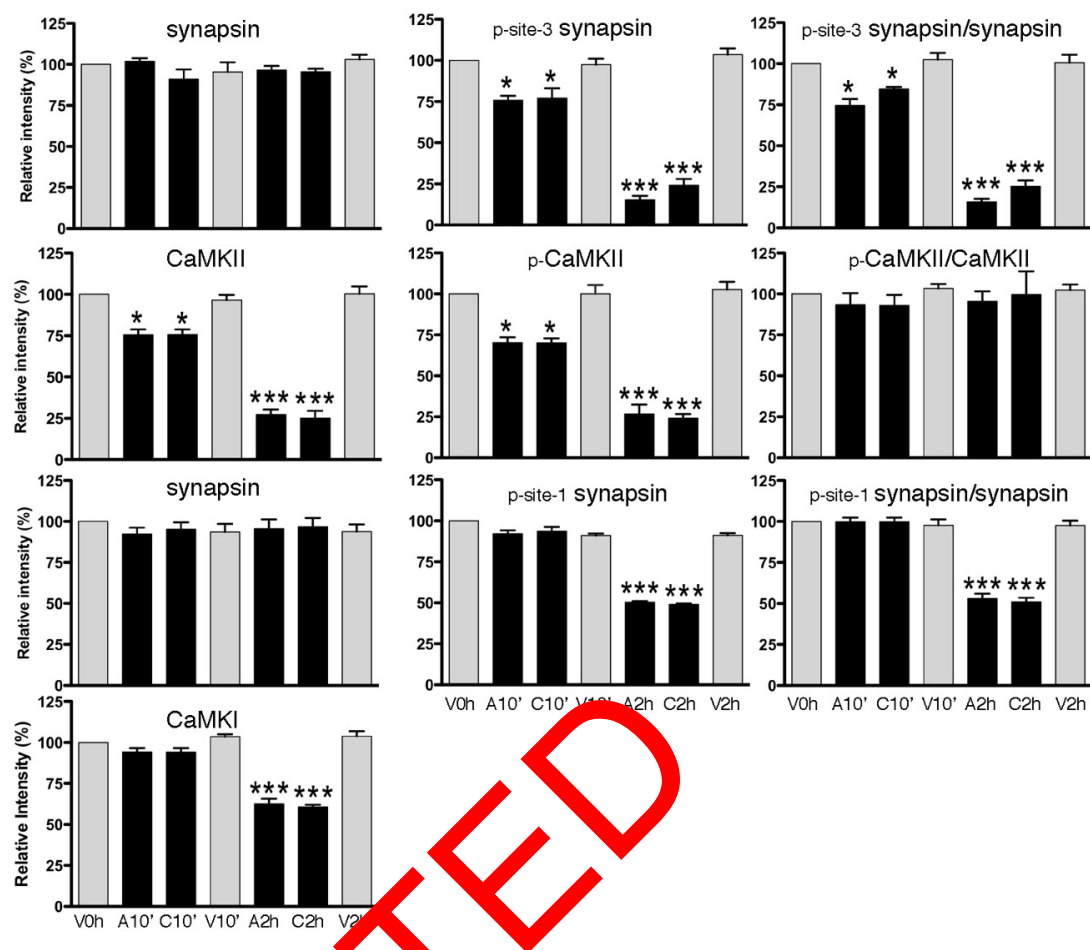

VOh A10' C10' ${ }^{\prime}$ 2h C2h V2h VOh A10' C10' V10' A2h C2h V2h
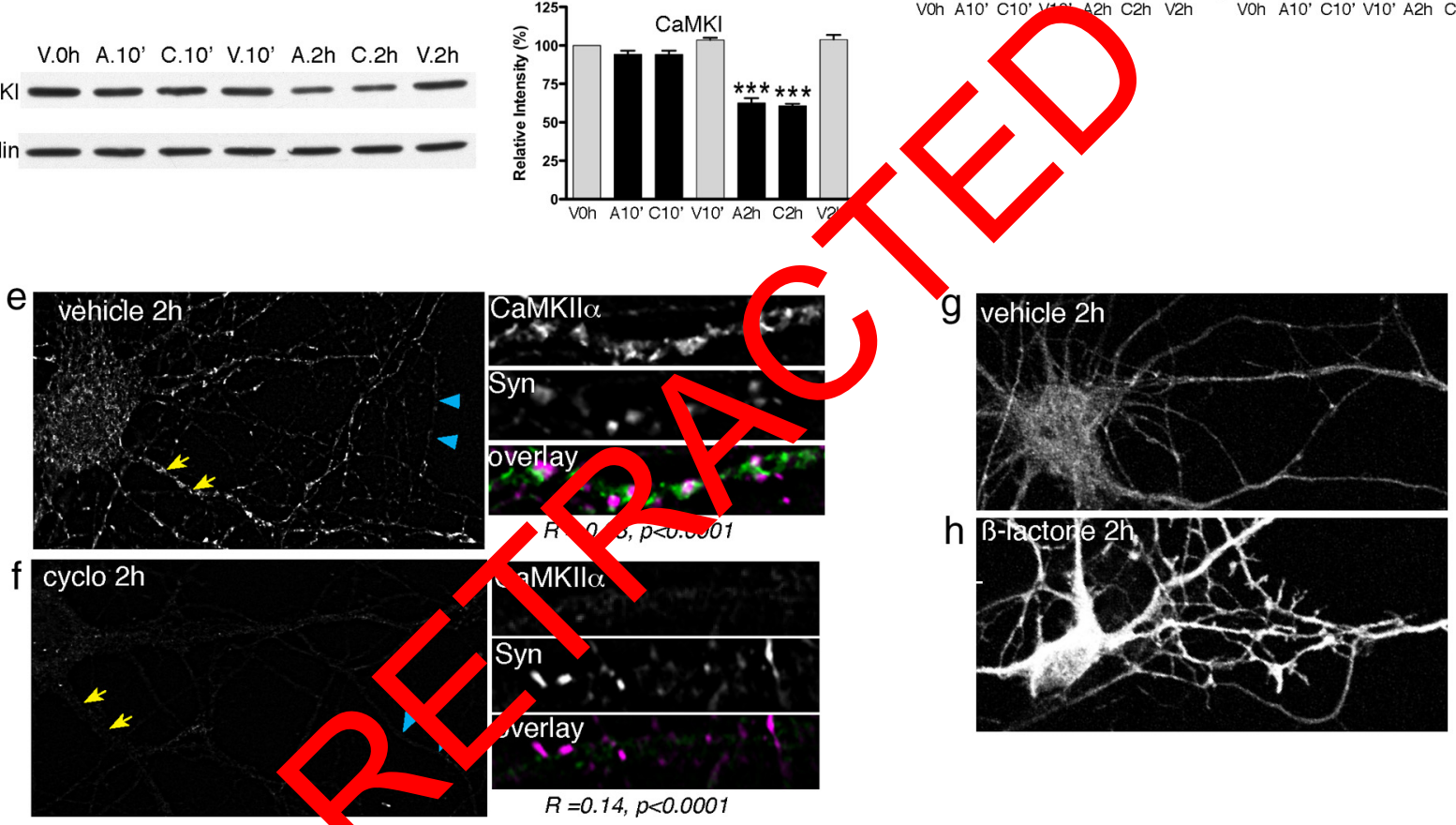

$R=0.14, p<0.000$

Figure 6. Rapid turnover makes CaMKIl $\alpha$ a target for regulation by protein synthesis. $\boldsymbol{a}-\boldsymbol{d}$, Images of representative Western blots are shown on the left and quantitative analyses are shown in bar graphs on the right. Whole-cell lysates were taken from young cultured hippocampal neurons after exposure to reagents shown for the times indicated. $\boldsymbol{a}$, Total levels of synapsin I are stable, butp-site-3 synapsin I levels decrease significantly after 10 min and substantially after $2 \mathrm{~h}$ exposure to aniso (A) or cyclo (C) relative to vehicle (V) controls. $\boldsymbol{b}$, A decrease in total CaMKIl $\alpha$ levels is significant by 10 min aniso or cyclo and nearly absent by $2 \mathrm{~h}$. p-CaMKII $\alpha$ shows a similar pattern. $\boldsymbol{c}$, $\boldsymbol{d}$, P-site-1 synapsin I levels decrease at $2 \mathrm{~h}$ coincident with the decrease in total CaMKI levels (tubulin was used as a loading control). $\boldsymbol{e}$, Immunolabeling indicates that CaMKIl $\alpha$ is heterogeneously distributed in axons (blue arrowheads) and dendrites (yellow arrows) and at higher magnification at right. The distributions of CaMKII labeling (green in overlay and top panel) positively correlates with synaptophysin labeling (magenta in overlay and middle panel) ( $R$ value is indicated). $f$, CaMKIl $\alpha$ levels diminish throughout neurons after protein synthesis inhibition (labeling as in $\boldsymbol{e}$ ). Although the distributions of CaMKIl $\alpha$ and synaptophysin remain correlated, the correlation decreases. $\boldsymbol{g}, \boldsymbol{h}$, Confocal images show that $2 \mathrm{~h}$ proteasome inhibition (10 $\mu$ m clasto-lactacystin $\beta$-lactone) leads to a $75 \%$ increase in the average intensity of CaMKIl $\alpha$ immunolabeling throughout neurons. For Western blots, quantitative data are averages from three separate cultures ( $n=3$ ). Groups were compared using a one-way ANOVA and Bonferroni's post-test: ${ }^{*} p<0.05,{ }^{* * *} p<0.001$ relative to vehicle control. Error bars indicate SEM. For analysis of codistribution, Pearson's correlation coefficient was calculated based on line scans drawn through dendrites from at least nine neurons per condition.

exposed young neurons to the cell-permeable, irreversible proteasome inhibitor clasto-lactacystin $\beta$-lactone for $2 \mathrm{~h}$, and immunolabeled for CaMKII $\alpha$. After proteasome inhibition, there was a $75 \%$ increase in the average intensity for CaMKII $\alpha$ when compared with vehicle controls (unpaired, two-tailed $t$ test, $p<0.001$ ) (Fig. $6 g, h$ ). Thus, CaMKII $\alpha$ undergoes rapid synthesis and degradation.

\section{CaMKII regulates presynaptic activity}

Since CaMK levels decrease rapidly in response to protein synthesis inhibition in young neurons, we asked whether
CaMK activity regulates vesicle recycling similar to protein synthesis inhibition. To test this, we exposed young neurons to KN93, a selective inhibitor for CaMKI and -II (Hook and Means, 2001), to KN92, an inactive structural analog, or to vehicle, and assessed FM dye recycling. Similar to what we observed after protein synthesis inhibition, neurons exposed to KN93 showed a significant reduction in FM dye uptake (Fig. $7 a, c)$, small sites were more strongly affected than large sites (Fig. $7 e, g$ ), and FM dye release was greatly reduced (Fig. $7 a, d$, f). Additionally, $11 \%$ of all recycling sites and $16 \%$ of small sites were lost, similar to the losses observed after protein 
a

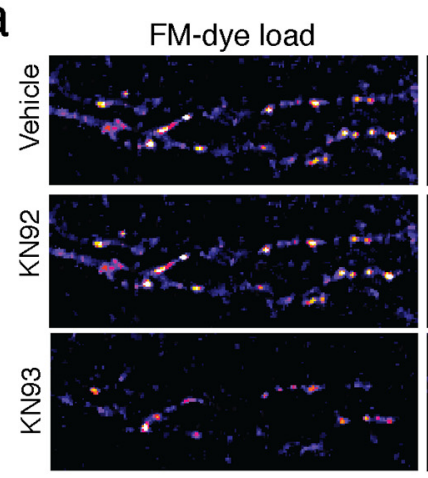

C

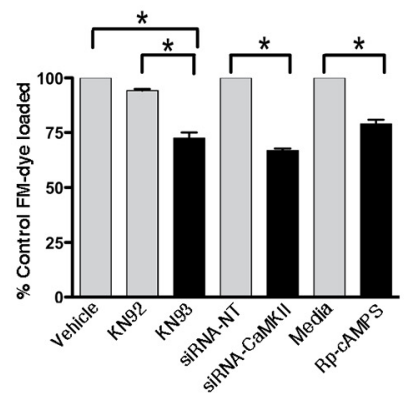

f

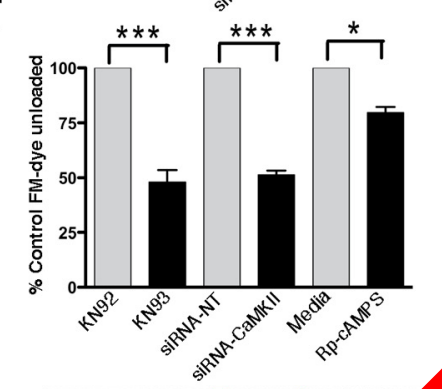

i
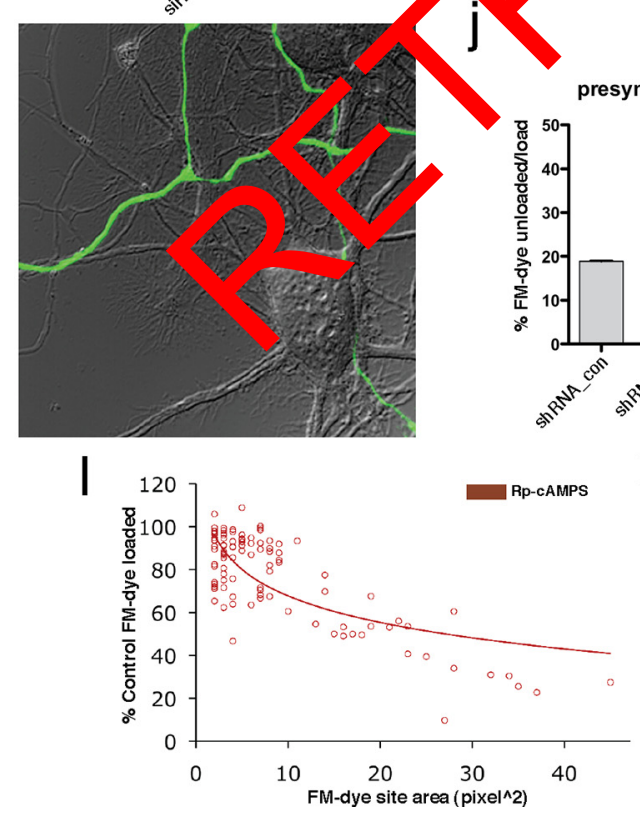

FM-dye unload

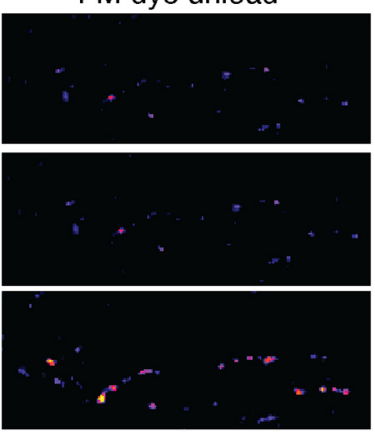

d

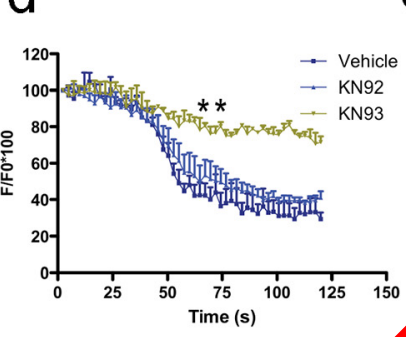

g

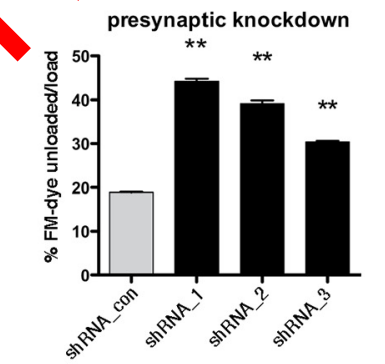

$\mathrm{m}$ b

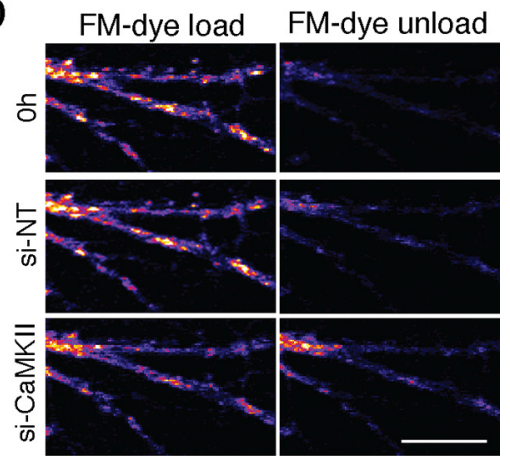

e 120 .

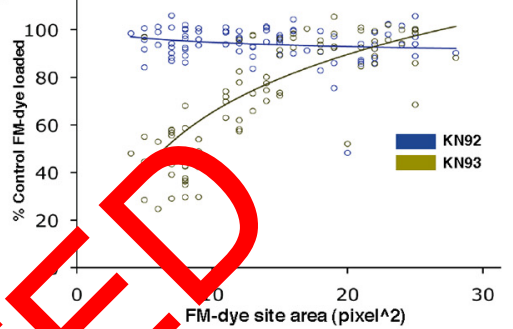

h

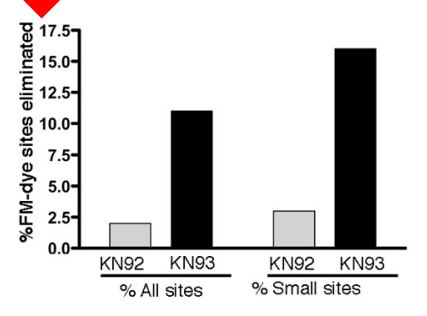

$\mathrm{k}$
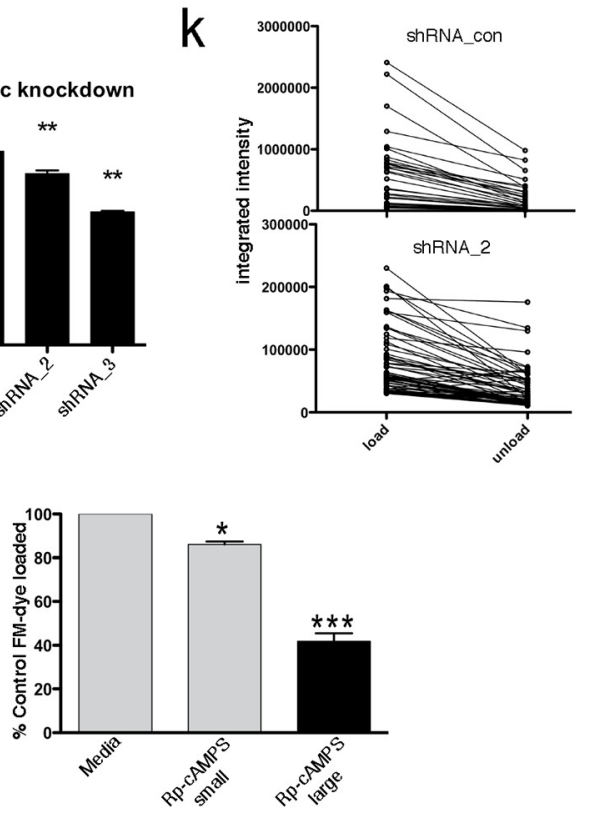

Figure 7. CaMKII $\alpha$ regulates vesicle availability in young neurons. $\boldsymbol{a}$, Confocal images show FM dye uptake (left column) and release (right column) in the same young neuron after $1 \mathrm{~h}$ vehicle (top row), after $1 \mathrm{~h} \mathrm{KN92} \mathrm{(middle),} \mathrm{and} \mathrm{after} 1 \mathrm{~h} \mathrm{KN93}$ (bottom row). KN93 reduces uptake and greatly reduces release, similar to protein synthesis inhibition. $\boldsymbol{b}$, Confocal images show FM dye uptake (left column) and release (right column) in the same young neuron at $t=0$ (top row), after $6 \mathrm{~h}$ si-NT (nontargeting, negative control siRNA; middle), and after $6 \mathrm{~h}$ si-CaMKII (siRNAs targeting CaMKIl $\alpha$; bottom row). $\boldsymbol{C}$, Quantitative analysis of the intensities of all FM dye sites after loading shows that CaMKI/II inhibition with KN93 decreases FM dye uptake relative to KN92 (control) or vehicle alone. siRNA-CaMKII similarly decreases uptake when compared with negative control. PKA inhibition with RpcAMPS also reduces dye uptake, but the magnitude is less. $\boldsymbol{d}$, FM dye release (Figure legend continues.) 
synthesis inhibition, and substantially greater than after KN92 (2\%) (Fig. 7h). Thus, CaMK inhibition regulates vesicle pool availability and the maintenance of presynaptic terminals in a manner that closely resembles protein synthesis inhibition.

KN93 inhibits both CaMKI and CaMKII activity. To determine which kinase accounts for the protein synthesis-mediated decreases in presynaptic function, we used two approaches. First, we examined FM dye uptake and release in young neurons exposed to STO-609, a selective antagonist of CaMKK, the upstream activator of CaMKI (Tokumitsu et al., 2002). We observed no differences relative to vehicle controls (supplemental Fig. 7, available at www.jneurosci.org as supplemental material) suggesting that CaMKII is the principal target for KN93-triggered deficits in presynaptic function.

In the second approach, we used Accell siRNAs, which enter cells in the absence of transfection reagents, to knock down CaMKII $\alpha$ levels. In control experiments, CaMKII $\alpha$ siRNAs greatly diminished CaMKII $\alpha$ immunostaining in neurons within $6 \mathrm{~h}$, a time frame that is consistent with the rapid turnover of the kinase (supplemental Fig. $8 a, b$, available at www.jneurosci.org as supplemental material). We then exposed neurons to a negative control pool of siRNAs for $6 \mathrm{~h}$, loaded and unloaded FM dye, and compared the values to baseline $(t=0)$. The control siRNAs produced no significant changes in recycling (Fig. $7 b, c, f)$. After $6 \mathrm{~h}$ exposure to CaMKII $\alpha$ siRNAs, the dye intensity after loading was reduced and, after unloading, increased relative to the control siRNA (Fig. $7 b, c, f)$. Thus, altered presynaptic terminal function after CaMKII $\alpha$ knockdown is virtually identical with that observed after KN93, and together, the data strongly support that protein synthesis inhibition mediates its effects on presynap $c$ terminals by decreasing CaMKII availability (Fig. $7 c, f)$.

Presynaptic CaMKII can regulate presynaptic func on Sustained postsynaptic overexpression of con atutiv active and inactive forms of CaMKII $\alpha$ can retrograd $y$ rulate psynaptic function via homeostatic mechanism but in the circumstances postsynaptic responses are alter as wll (Wu et al., 1996; Haghighi et al., 2003; Pratt et al., 2003). ro cin syathesis inhibi-

$\leftarrow$

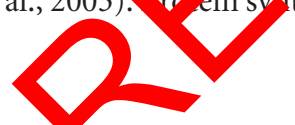

(Figure legend continued.) kinetics over 120 s after shicle, KN92, or KN93. KN93 nearly prevents release. $\boldsymbol{e}$, Scatter plots and best-fit curves of FM dye uptake as a function of FM dye site area after KN92 (blue) and KN93 (gold). $\boldsymbol{f}$, Dye intensities after FM dye unloading under the conditions indicated. CaMK inhibition and knockdown greatly diminish dye release and PKA inhibition has a lesser impact. $\boldsymbol{g}$, After CaMK inhibition, small sites account for the decreased dye uptake observed in the total population. Large sites do not change relative to KN92-treated controls. $\boldsymbol{h}$, The percentage of FM dye sites eliminated in response to KN93 is very similar to that in response to translation blockade (Fig. $4 a$ ). $\boldsymbol{i}$ - $\boldsymbol{k}$, Confocal and DIC overlay image shows GFPlabeled (and shRNA_1-expressing) axons contacting an unlabeled cell body and dendrites. Accompanying graph shows that either presynaptic CaMKII $\alpha$ knockdown with any of three shRNAs (supplemental Fig. 8, available at www.jneurosci.org as supplemental material) increases the ratio $I_{\text {unloading }} / I_{\text {loading }}$ significantly relative to shRNA_con. Comparisons of loading and unloading intensity values taken from a subset of the data $(\boldsymbol{k})$ show the increased ratio is attributable principally to an increase in unloading intensity. $I, \boldsymbol{m}, \mathrm{A}$ scatter plot and best-fit curve ofFM dye loaded as a function of FM dye site area after PKA inhibition (red) shows that the decrease in FM dye loading (I) becomes greater as sites become larger-the inverse of KN93 (compare with $\boldsymbol{e}$ ). The bar graph illustrates the magnitude and significance of this difference (m). Data are based on $78<n<100$ FM dye sites for each condition (from at least 4 neurons and 2 separate cultures) for CaMKI/II inhibition, $n=236$ for siRNA inhibition ( 3 neurons, 2 separate cultures), and $n=116$ sites (from at least 4 neurons from 2 separate experiments) for PKA inhibition. Groups were compared using repeated-measures ANOVA and Tukey's post-test $(\boldsymbol{c})$, one-way ANOVA $(\boldsymbol{j})$, or paired $t$ tests (siRNA, Rp-CAMPS in $\mathbf{c}$ and all others). The asterisks represent statistical significance with respect to control at ${ }^{*} p<0.05,{ }^{* *} p<0.001$, and ${ }^{* * *} p<0.0001$. Error bars indicate SEM. Scale bar, $14.2 \mu \mathrm{m}$. tion does not alter postsynaptic responses (Fig. 2), suggesting that presynaptic CaMKII is the more likely functional target for protein synthesis inhibition. It is well established that presynaptic CaMKII $\alpha$ can regulate vesicle release directly (Llinás et al., 1985). To determine the contribution of endogenous presynaptic CaMKII $\alpha$ to presynaptic function in young neurons, we selectively knocked down CaMKII $\alpha$ levels by expressing GFP and shRNAs targeting CaMKII $\alpha$ or a control shRNA in a small population of neurons (supplemental Figs. $8 c, 7 i$, available at www.jneurosci.org as supplemental material) (see Materials and Methods). The intensity of FM dye was then assayed in GFP-labeled axons at sites contacting untransfected dendrites after loading and unloading, and the ratio of the values (unload/load) was used to compare across neurons. In neurons expressing control shRNAs presynaptically, FM dye uptake and release were similar to untransfected neurons: dye intensity achieved after uptake was reduced by $\sim 80 \%$ after unloading (Fig. $7 j, k$ ). After presynaptic knockdown of CaMKII $\alpha$, there was a significant increase in the ratio, and decrease release was the principal contributor to this differep (Fig.,$k$ ). Postsynaptic knockdown of CaMKII $\alpha$ also sign antly hcreased the ratio as expected (supplementa Fig. $8 d$, ailable at www.jneurosci.org as supplementa m? crial) These data indicate that decreased presynar ic Ca. KII Aevels can directly impact presynaptic termi al nction.

\section{aMKII and PKA act differentially at small and large sites}

Vork in hore mature neurons suggests that PKA plays a more p. min at role regulating synapsin and presynaptic function than CaMKII (Menegon et al., 2006). To determine the contributron of PKA to vesicle recycling in young neurons, we assayed FM dye uptake and release in the presence of a PKA inhibitor, Rp-cAMPS. Neurons exposed to Rp-cAMPS showed reduced FM dye uptake, and the degree of reduction was similar to that seen in neurons exposed to KN93 (Fig. 7c). However, when the data are plotted as a function of puncta area, it can be seen that Rp-cAMPS targets large FM dye sites, whereas KN93 targets small ones (Fig. 7 , compare $l, m$ with $e, g)$. In the presence of Rp-cAMPS, release was also reduced, but the magnitude was far less than in neurons exposed to KN93 (Fig. 7f). Thus, CaMKII activity predominates regulation at small terminals, whereas PKA activity predominates at large terminals.

\section{PKA is anchored by AKAPs at large sites}

Since PKA is present in neurons at all of the stages we examined (Hudmon et al., 2005; Menegon et al., 2006), we asked what could account for its differential actions at small and large presynaptic terminals. A likely possibility lies with the mechanisms responsible for PKA localization. AKAPs bind PKA regulatory subunits, and by tethering the kinase in distinct cellular compartments, serve to impart spatial and temporal specificity (Wong and Scott, 2004).

We asked whether the large terminals, which are more sensitive to PKA inhibition, are better able to recruit and retain PKA via AKAPs. To test this, we assayed FM dye uptake and release in young neurons after exposure to St-Ht31, a stearated (and permeable) peptide that competitively antagonizes PKA anchoring by mimicking an $\alpha$-helical domain used by all known AKAPs to bind PKA subunits, or to a similarly modified control peptide (Vijayaraghavan et al., 1997). When the data from all labeled sites were analyzed together, the blocking peptide (St-H31) showed a modest effect on uptake and release similar to what is observed after PKA inhibition (Fig. 8a) (15\% reduction in uptake and a 

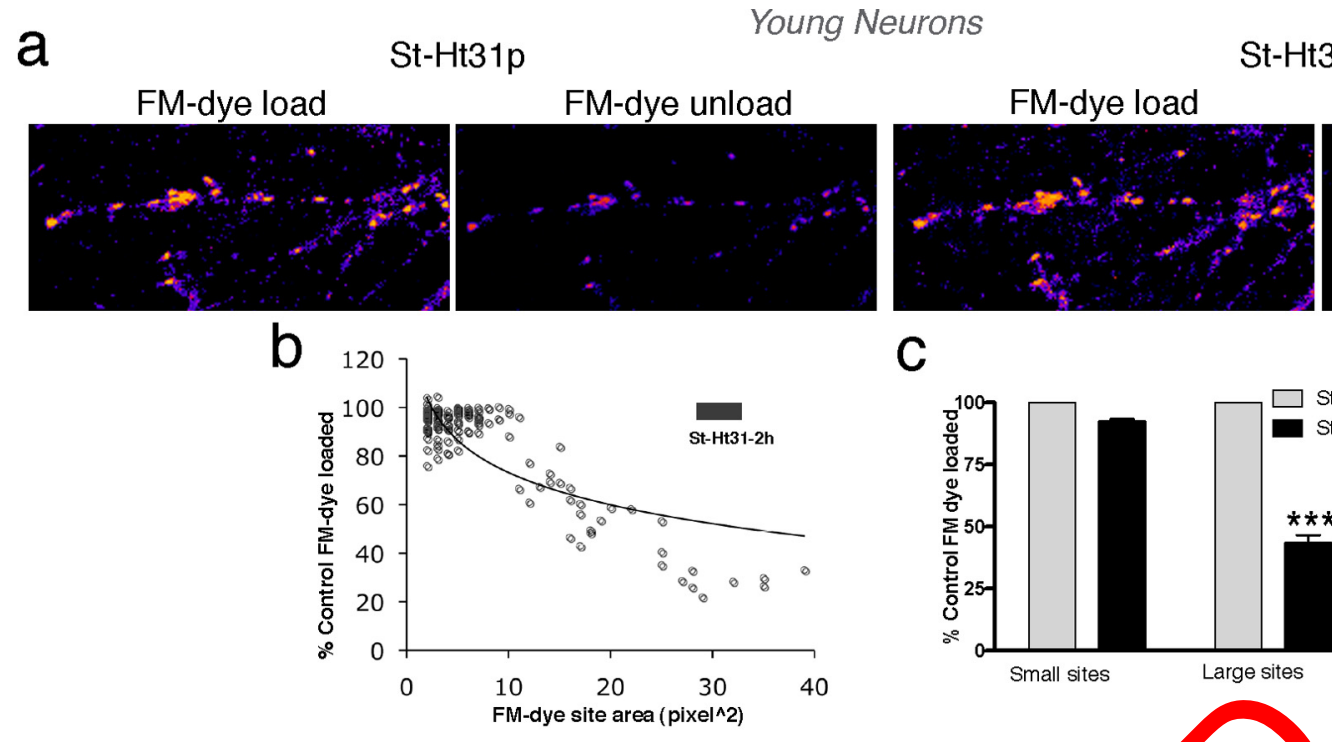

\section{C}
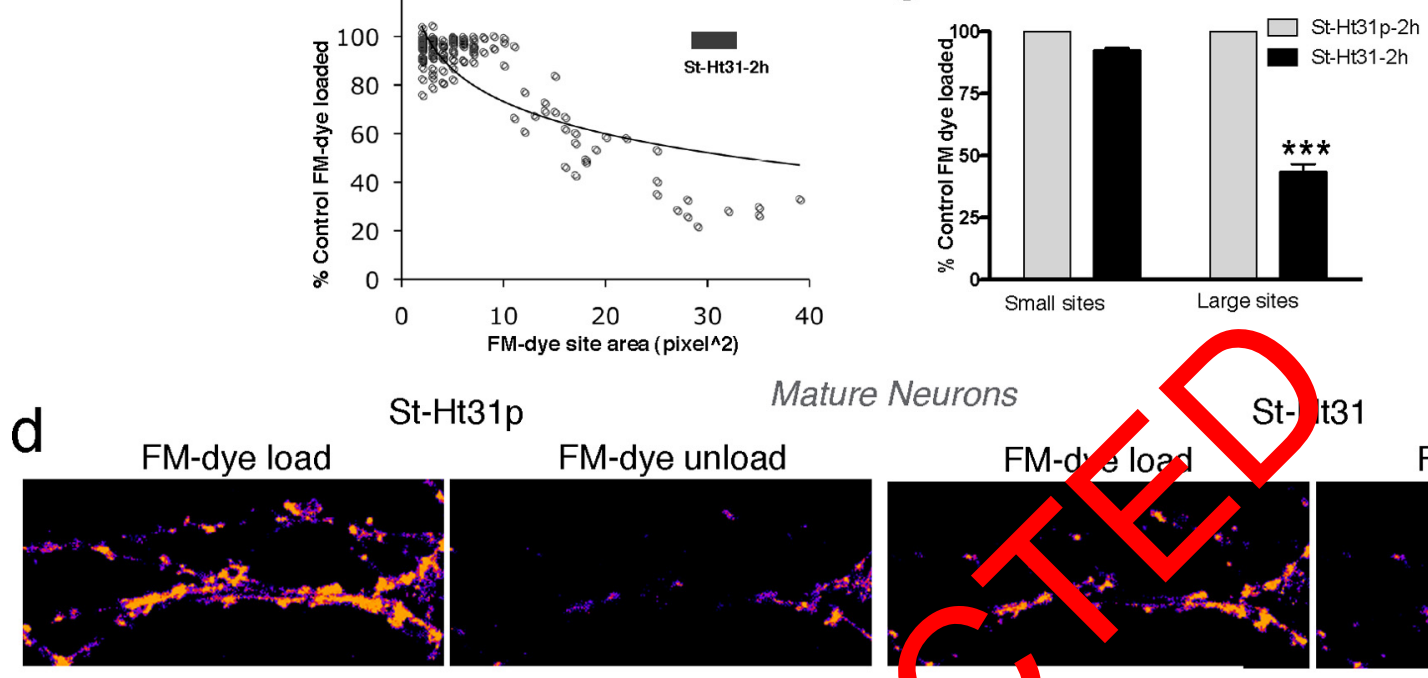

t-Ht31p

Mature Neurons
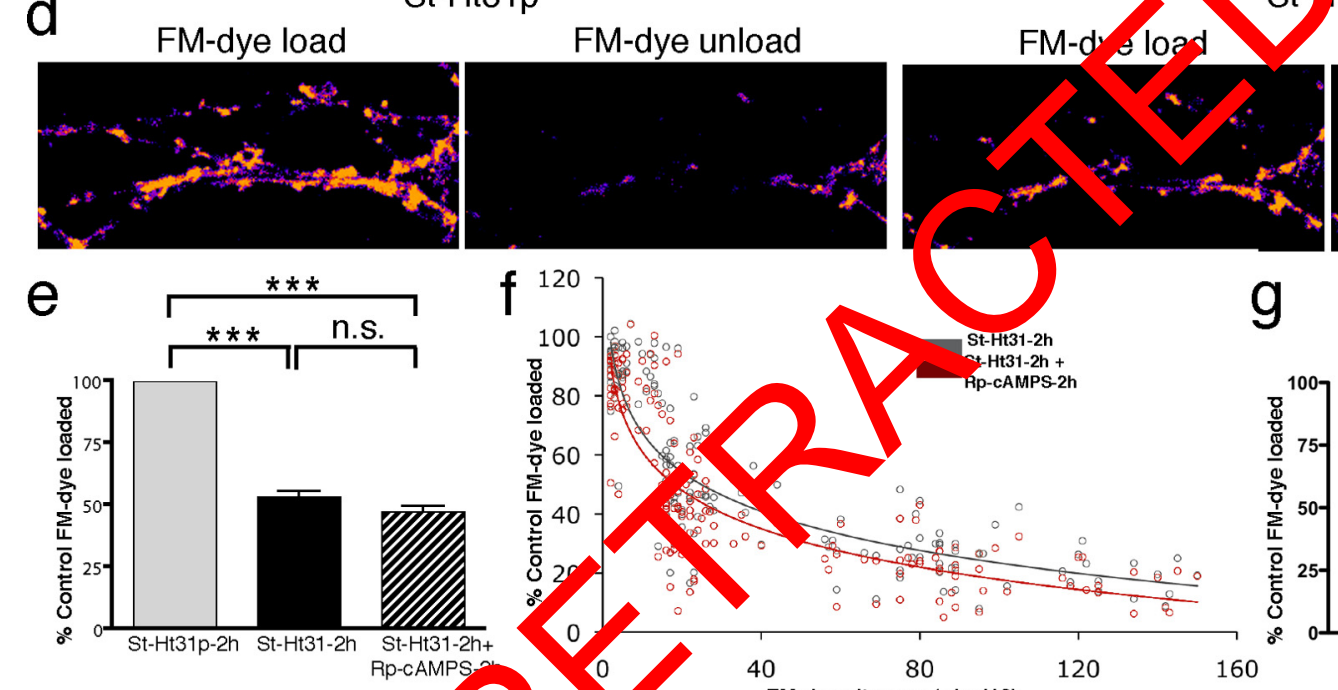
It31

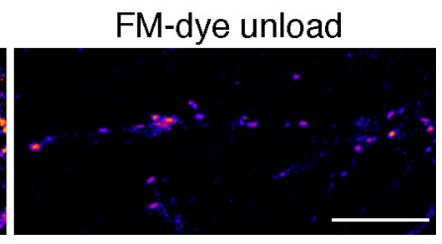

unload

. 
CaMKII $\alpha$. Its levels diminish rapidly in the absence of new synthesis, and we show that smaller terminals depend on the actions of CaMKII to maintain a functional recycling pool. In contrast, larger terminals, more abundant in mature neurons, rely on PKA activity that is anchored by AKAPs. Thus, protein synthesis maintains and regulates CaMKII-dependent functions at young synapses. These data support a novel regulatory mechanism whereby rapid protein turnover coupled with short-term translational silencing provides a means by which certain synapses may be selectively disadvantaged and eliminated (Fig. 9).

\section{Ongoing protein synthesis maintains the synaptic vesicle recycling pool} After addition of protein synthesis inhibitors, there is a selective decrease in the size and function of the recycling pool of synaptic vesicles at small synaptic terminals that leaves the RRP intact.

This effect occurs rapidly and at nearly every site in young neurons. The RRP, identified by stimulation with hypertonic sucrose, appears unaffected by protein synthesis inhibition, a finding that is consistent with the maintenance of EPSCs (or minis), which are generated by spontaneous vesicle fusion. The decrease in activity-dependent recycling, vesicle cluster size, altered synapsin function, and depressed postsynaptic responses to bursti activity are most consistent with the interpretation that pro tein synthesis inhibition prevents the efficient recrui men of a recycling pool of vesicles essential during perioc of stimulation. Defects in endocytosis may also stribu to the diminished pool size labeled with FM dye, at rolongn 8 the loading period did not increase the labele pool sus esting that endocytosis is not the principal target Tim lapse imaging of vesicle markers shows small clusters bre roway from the parent cluster, suggesting there is a en t in es anchoring (J. Sebeo and D. L. Benson, unpu isher results). An anchoring defect would also be expected to imp vesicle recruitment and transport toward the active zone produch the "trapped" vesicles that remain in terminals after unloading (Fig. 1). The preservation of a RRP is consistent with several lines of data demonstrating that vesicle pools can be regulated independently (Pyle et al., 2000; Rizzoli and Betz, 2004), and also indicates that high-frequency or sustained activity will be most prominently impacted by decreased protein synthesis.

\section{Synapse elimination}

Protein synthesis inhibition reduces presynaptic function in the vast majority of small boutons. Twelve percent of these sites are eliminated and are not reestablished over a $4 \mathrm{~h}$ recovery period-nearly a fivefold increase over control conditions. The numbers of sites having detectable clusters of presynaptic and postsynaptic proteins are also reduced, indicating that bona fide synapses are lost. In light of this, a decrease in the frequency of mEPSCs might be expected after protein synthesis inhibition, but we observed no significant differences. It appears that mEPSC frequency in young neurons is either too low to reliably detect small changes in numbers, or that most of the events recorded are dominated by large terminals.

To generate appropriate connectivity during development, synapses are both formed and eliminated, but few mechanisms have bee Aden red th at destabilize developing synapses. Our data $d$, whell we recent experiments demonstrating that sustained ( $\mathrm{h}$ ) inhibition of protein synthesis can destabilize en mature mammalian neuromuscular junctions (McCann et 1., 2007) and together they suggest that mechanisms that supp. ss tra slation of particular proteins (e.g., microRNAs) or several proteins [e.g., elongation factor regulation, FMRP (fragile X mental retardation protein)], many of which can be regulated locally, help to identify particular synapses for elimination. In the mammalian visual system, members of the complement cascade enable the process of elimination (Stevens et al., 2007), but their broad distribution suggests additional factors contribute toward selectivity. Consistent with this idea, in Caenorhabditis elegans, an E3 ubiquitin ligase can trigger neuromuscular synapse elimination, but only in the absence of a protective interaction that serves to sequester the ligase (Ding et al., 2007). These data suggest a model in which suppressing translation may serve to remove such a protective factor.

\section{CaMKII and presynaptic function}

We show that, in young neurons, CaMKII $\alpha$ levels diminish rapidly when translation is inhibited and rise rapidly in the presence of proteasome inhibitors. Thus, CaMKII $\alpha$ is constitutively synthesized and rapidly turned over, providing a seemingly costly, but highly effective means by which its concentration can be tightly controlled. Previous work has highlighted the importance of controlled degradation in the development of Drosophila neuromuscular junction as loss of either of the ubiquitin ligases PHR (Pam/Highwire/RPM) or APC (anaphase promoting complex) leads to synapse overgrowth (DiAntonio et al., 2001; van Roessel et al., 2004). The studies here demonstrate that a continuous line of new synthesis is equally important, even over short time intervals. This provides a means to rapidly control protein concentration particularly during a stage in development when synapses lack well developed compartments and a full complement of scaffolding proteins that serve to trap, anchor, and accumulate particular proteins. Consistent with this idea, as neurons mature, CaMKII $\alpha$ levels rise dramatically (Bayer et al., 1999), and its accumulation and concentration within postsynaptic densities coincide with an increase in its stability (supplemental Fig. 6, 
available at www.jneurosci.org as supplemental material) (Ehlers, 2003). Mature presynaptic terminals appear to continue to use turnover as a regulatory mechanism since brief periods of proteasome inhibition in more mature preparations of neurons can enhance vesicle release (Willeumier et al., 2006; Yao et al., 2007).

$\mathrm{CaMKII} \alpha$ is unlikely to be the only protein responsive to protein synthesis inhibition, but the similarity in outcomes after protein synthesis inhibition, CaMKII inhibition, or knockdown indicates that CaMKII is a key effector. Several studies support that changes in total or postsynaptic CaMKII activity can alter the progression of synaptogenesis. In C. elegans, loss of functional CaMKII results in a decreased density of excitatory postsynaptic sites (Rongo and Kaplan, 1999). Sustained postsynaptic overexpression of constitutively active CaMKII $\alpha$ promotes postsynaptic maturation in Xenopus optic tectum (Wu et al., 1996) and increases synaptic strength and stability in rat cortical neurons (Pratt et al., 2003, 2008). We show that presynaptic reductions in endogenous CaMKII $\alpha$ can also directly regulate presynaptic function in young neurons, consistent with several lines of data in a variety of preparations that show increased levels of exogenous presynaptic CaMKII promote neurotransmitter release (Llinás et al., 1985; Nichols et al., 1990). More significantly, the data show that CaMKII activity can be controlled, in part, by its turnover, and the ease with which CaMKII levels can be regulated provides additional support for the idea that individual synapses can titrate kinase concentration as well as activation and phosphorylation state (Aakalu et al., 2001; Sutton et al., 2004).

\section{Local control}

A local gradient of aniso applied to presynaptic terminals dendrites rapidly reduces the pool of vesicles available for fusio similar to bath application, while terminals on nearby ell b dies lying outside the gradient are unaffected. This a that the effect of protein synthesis on presynap term als can be mediated locally.

A wealth of data supports that dendrit can trate particular proteins including CaMKII $\alpha$ (Stey d an Schuman, 2001), and that postsynaptic changes in CaMK $\alpha$ anction can be communicated retrogradely to presyn otr tern nal (Haghighi et al., 2003; Pratt et al., 2003), but fir that hort-term protein synthesis inhibition has no effec, postsynaptic function. Presynaptic terminals in mammals a generally thought to be devoid of the machinery and capacity to synthesize proteins (Giuditta et al., 2002), but recent work suggests this idea requires revision (Taylor et al., 2009). Developing axons contain proteins relevant for translational regulation (Christie et al., 2009), and axonal growth cones generate and degrade proteins locally $(\mathrm{Wu}$ et al., 2005; Leung et al., 2006; Yao et al., 2006). Neurites in invertebrates have characteristics of both axons and dendrites, but it is significant that suppression of an mRNA that concentrates presynaptically inhibits synapse assembly (Lyles et al., 2006). Thus, rapid and local protein synthesis and degradation are likely contributors to presynaptic and postsynaptic development and differentiation.

\section{A CaMKII to PKA switch}

As synapses mature and grow larger, CaMKII actions on vesicle recycling appear to be replaced by PKA. In more mature hippocampal neurons, PKA more predominantly regulates FM dye recycling (Fig. 8) as well as synapsin I (Hosaka et al., 1999; Menegon et al., 2006; Sun et al., 2006; Willeumier et al., 2006). Larger terminals use PKA based on their ability to recruit AKAPs, which localize PKA activity. We find that blocking AKAP binding mim- ics the effects of PKA inhibition on vesicle recycling. AKAPs anchor and concentrate PKA postsynaptically to affect a variety of critical actions relevant for synapse plasticity (Rosenmund et al., 1994; Snyder et al., 2005; Huang et al., 2006; Smith et al., 2006), but our findings suggest that PKA anchoring at presynaptic sites may also be equally important. Consistent with this idea, conditional expression of $\mathrm{Ht} 31$ peptide in the CA3 region of hippocampus critically impacts L-LTP (late-phase LTP) recorded postsynaptically in CA1, as well as a hippocampal-dependent spatial memory task (Nie et al., 2007). Collectively, the data indicate that the endogenous pathway used to regulate vesicle recycling depends on the age of the neuron and stage of synapse development, similar to what has been described previously for postsynaptic responses (Yasuda et al., 2003).

\section{References}

Aakalu G, Smith WB, Nguyen N, Jiang C, Schuman EM (2001) Dynamic visualization of local protein synthesis in hippocampal neurons. Neuron 30:489-502.

Abraham WC, William M (20 Properties and mechanisms of LTP maintenance. Neuros entist 9:4, 3-474.

Alberini CM $\left(200^{\circ}\right.$ The ro of p tein synthesis during the labile phases of memory: re siting ske 1 sm. Neurobiol Learn Mem 89:234-246.

Alberts B, Jol Mso, Lewis Raff M, Roberts K, Walter P (2002) Molecular biolo of the $\mathrm{co} \mathrm{Ne}$ York: Garland Science.

Bayer I L ler J, Sc, Mman H, Harbers K (1999) Developmental expresion of the $\mathrm{M}$ kinase II isoforms: ubiquitous gamma- and delta-CaM kinase II are me early isoforms and most abundant in the developing nervou system. Brain Res Mol Brain Res 70:147-154.

tz WJ, N lo F, Bewick GS (1992) Activity-dependent fluorescent staining staining of living vertebrate motor nerve terminals. J Neurosci 12:363-375.

Betz WJ, Mao F, Smith CB (1996) Imaging exocytosis and endocytosis. Curr Opin Neurobiol 6:365-371.

Birmingham A, Anderson EM, Reynolds A, Ilsley-Tyree D, Leake D, Fedorov Y, Baskerville S, Maksimova E, Robinson K, Karpilow J, Marshall WS, Khvorova A (2006) 3' UTR seed matches, but not overall identity, are associated with RNAi off-targets. Nat Methods 3:199-204.

Bresler T, Ramati Y, Zamorano PL, Zhai R, Garner CC, Ziv NE (2001) The dynamics of SAP90/PSD-95 recruitment to new synaptic junctions. Mol Cell Neurosci 18:149-167.

Cano E, Hazzalin CA, Mahadevan LC (1994) Anisomycin-activated protein kinases p45 and p55 but not mitogen-activated protein kinases ERK-1 and -2 are implicated in the induction of c-fos and c-jun. Mol Cell Biol 14:7352-7362.

Carr DW, Hausken ZE, Fraser ID, Stofko-Hahn RE, Scott JD (1992a) Association of the type II cAMP-dependent protein kinase with a human thyroid RII-anchoring protein. Cloning and characterization of the RIIbinding domain. J Biol Chem 267:13376-13382.

Carr DW, Stofko-Hahn RE, Fraser ID, Cone RD, Scott JD (1992b) Localization of the cAMP-dependent protein kinase to the postsynaptic densities by A-kinase anchoring proteins. Characterization of AKAP 79. J Biol Chem 267:16816-16823.

Christie SB, Akins MR, Schwob JE, Fallon JR (2009) The FXG: a presynaptic fragile X granule expressed in a subset of developing brain circuits. J Neurosci 29:1514-1524.

De Paola V, Arber S, Caroni P (2003) AMPA receptors regulate dynamic equilibrium of presynaptic terminals in mature hippocampal networks. Nat Neurosci 6:491-500.

DiAntonio A, Haghighi AP, Portman SL, Lee JD, Amaranto AM, Goodman CS (2001) Ubiquitination-dependent mechanisms regulate synaptic growth and function. Nature 412:449-452.

Dick LR, Cruikshank AA, Grenier L, Melandri FD, Nunes SL, Stein RL (1996) Mechanistic studies on the inactivation of the proteasome by lactacystin: a central role for clasto-lactacystin beta-lactone. J Biol Chem 271:7273-7276.

Dictenberg JB, Swanger SA, Antar LN, Singer RH, Bassell GJ (2008) A direct role for FMRP in activity-dependent dendritic mRNA transport links filopodial-spine morphogenesis to fragile $\mathrm{X}$ syndrome. Dev Cell 14:926-939. 
Ding M, Chao D, Wang G, Shen K (2007) Spatial regulation of an E3 ubiquitin ligase directs selective synapse elimination. Science 317:947-951.

Echeverri CJ, Perrimon N (2006) High-throughput RNAi screening in cultured cells: a user's guide. Nat Rev 7:373-384.

Ehlers MD (2003) Activity level controls postsynaptic composition and signaling via the ubiquitin-proteasome system. Nat Neurosci 6:231-242.

Elbashir SM, Martinez J, Patkaniowska A, Lendeckel W, Tuschl T (2001) Functional anatomy of siRNAs for mediating efficient RNAi in Drosophila melanogaster embryo lysate. EMBO J 20:6877-6888.

Feany MB, Lee S, Edwards RH, Buckley KM (1992) The synaptic vesicle protein SV2 is a novel type of transmembrane transporter. Cell 70:861-867.

Fletcher TL, Cameron P, De Camilli P, Banker G (1991) The distribution of synapsin I and synaptophysin in hippocampal neurons developing in culture. J Neurosci 11:1617-1626.

Frey U, Krug M, Reymann KG, Matthies H (1988) Anisomycin, an inhibitor of protein synthesis, blocks late phases of LTP phenomena in the hippocampal CA1 region in vitro. Brain Res 452:57-65.

Ghirardi M, Benfenati F, Giovedì S, Fiumara F, Milanese C, Montarolo PG (2004) Inhibition of neurotransmitter release by a nonphysiological target requires protein synthesis and involves cAMP-dependent and mitogen-activated protein kinases. J Neurosci 24:5054-5062.

Giuditta A, Kaplan BB, van Minnen J, Alvarez J, Koenig E (2002) Axonal and presynaptic protein synthesis: new insights into the biology of the neuron. Trends Neurosci 25:400-404.

Gomperts SN, Carroll R, Malenka RC, Nicoll RA (2000) Distinct roles for ionotropic and metabotropic glutamate receptors in the maturation of excitatory synapses. J Neurosci 20:2229-2237.

Goslin K, Asmussen H, Banker G (1998) Rat hippocampal neurons in lowdensity culture. In: Culturing nerve cells (Banker G, ed), pp 339-370. Cambridge, MA: MIT.

Graf ER, Zhang X, Jin SX, Linhoff MW, Craig AM (2004) Neurexins induce differentiation of GABA and glutamate postsynaptic specializations via neuroligins. Cell 119:1013-1026.

Haghighi AP, McCabe BD, Fetter RD, Palmer JE, Hom S, Goodman C (2003) Retrograde control of synaptic transmission by CaMKII at the Drosophila neuromuscular junction. Neur

Harata N, Ryan TA, Smith SJ, Buchanan J, Tsien RW recycling synaptic vesicles in hippocampal neuron conversion. Proc Natl Acad Sci U S A 98:12748-1

Hilfiker S, Pieribone VA, Czernik AJ, Kao HT, A šstine $\mathrm{G}$, Greengard P (1999) Synapsins as regulators of neurotra mitter release. Milos Trans R Soc Lond B Biol Sci 354:269-279.

Hook SS, Means AR (2001) $\mathrm{Ca}^{2+} / \mathrm{CaM}$ - and then activation to function. Annu Rev Pharmacol oxice 41:4 J5.

Hosaka M, Hammer RE, Südhof TC 1999 hospho-switch controls the dynamic association of synapsin with synaptic vesicles. Neuron 24:377-387.

Huang T, McDonough CB, Abel T (2006) Compartmentalized PKA signaling events are required for synaptic tagging and capture during hippocampal late-phase long-term potentiation. Eur J Cell Biol 85:635-642.

Huang YY, Nguyen PV, Abel T, Kandel ER (1996) Long-lasting forms of synaptic potentiation in the mammalian hippocampus. Learn Mem 3:74-85.

Hudmon A, Lebel E, Roy H, Sik A, Schulman H, Waxham MN, De Koninck P (2005) A mechanism for $\mathrm{Ca}^{2+} /$ calmodulin-dependent protein kinase II clustering at synaptic and nonsynaptic sites based on self-association. J Neurosci 25:6971-6983.

Jackson AL, Bartz SR, Schelter J, Kobayashi SV, Burchard J, Mao M, Li B, Cavet G, Linsley PS (2003) Expression profiling reveals off-target gene regulation by RNAi. Nat Biotechnol 21:635-637.

Katz LC, Shatz CJ (1996) Synaptic activity and the construction of cortical circuits. Science 274:1133-1138.

Kelleher RJ 3rd, Bear MF (2008) The autistic neuron: troubled translation? Cell 135:401-406.

Kleiman R, Banker G, Steward O (1993) Inhibition of protein synthesis alters the subcellular distribution of mRNA in neurons but does not prevent dendritic transport of RNA. Proc Natl Acad Sci U S A 90:11192-11196.

Klingauf J, Kavalali ET, Tsien RW (1998) Kinetics and regulation of fast endocytosis at hippocampal synapses. Nature 394:581-585.

Klussmann E, Maric K, Wiesner B, Beyermann M, Rosenthal W (1999) Protein kinase A anchoring proteins are required for vasopressin-mediated translocation of aquaporin-2 into cell membranes of renal principal cells. J Biol Chem 274:4934-4938.

Kole HK, Liotta AS, Kole S, Roth J, Montrose-Rafizadeh C, Bernier M (1996) A synthetic peptide derived from a $\mathrm{COOH}$-terminal domain of the insulin receptor specifically enhances insulin receptor signaling. J Biol Chem 271:31619-31626.

Krueger SR, Kolar A, Fitzsimonds RM (2003) The presynaptic release apparatus is functional in the absence of dendritic contact and highly mobile within isolated axons. Neuron 40:945-957.

Lanuza MA, Garcia N, Santafé M, González CM, Alonso I, Nelson PG, Tomàs J (2002) Pre- and postsynaptic maturation of the neuromuscular junction during neonatal synapse elimination depends on protein kinase C. J Neurosci Res 67:607-617.

Leung KM, van Horck FP, Lin AC, Allison R, Standart N, Holt CE (2006) Asymmetrical beta-actin mRNA translation in growth cones mediates attractive turning to netrin-1. Nat Neurosci 9:1247-1256.

Li Z, Zhang Y, Ku L, Wilkinson KD, Warren ST, Feng Y (2001) The fragile X mental retardation protein inhibits translation via interacting with mRNA. Nucleic Acids Res 29:2276-2283.

Lin X, Ruan X, Anderson MG, McDowell JA, Kroeger PE, Fesik SW, Shen Y (2005) siRNA-mediated off-target gene silencing triggered by a $7 \mathrm{nt}$ complementation. N

Linden DJ (1994) Lon term syna tic depression in the mammalian brain. Neuron 12:457

Llinás R, McGui cess TL, D A CS, Sugimori M, Greengard P (1985) Intratermir inje on of synapsin I or calcium/calmodulin-dependent protein mase alters curotransmitter release at the squid giant synapse c Natl A d ci U S A 82:3035-3039.

Lohof MM, Q Plan M, Dan Y, Poo MM (1992) Asymmetric modulation of Dsolic CA M activity induces growth cone turning. J Neurosci 12:1253-1261.

yles V, Zh o Y, Martin KC (2006) Synapse formation and mRNA localization ir cultured Aplysia neurons. Neuron 49:349-356.

Ma L, Zablow L, Kandel ER, Siegelbaum SA (1999) Cyclic AMP induces anctional presynaptic boutons in hippocampal CA3-CA1 neuronal cultures. Nat Neurosci 2:24-30.

McCann CM, Nguyen QT, Santo Neto H, Lichtman JW (2007) Rapid synapse elimination after postsynaptic protein synthesis inhibition in vivo. J Neurosci 27:6064-6067.

Meems R, Munno D, van Minnen J, Syed NI (2003) Synapse formation between isolated axons requires presynaptic soma and redistribution of postsynaptic AChRs. J Neurophysiol 89:2611-2619.

Menegon A, Bonanomi D, Albertinazzi C, Lotti F, Ferrari G, Kao HT, Benfenati F, Baldelli P, Valtorta F (2006) Protein kinase A-mediated synapsin I phosphorylation is a central modulator of $\mathrm{Ca}^{2+}$-dependent synaptic activity. J Neurosci 26:11670-11681.

Miller RL, Bukowski RM, Budd GT, Purvis J, Weick JK, Shepard K, Midha KK, Ganapathi R (1988) Clinical modulation of doxorubicin resistance by the calmodulin-inhibitor, trifluoperazine: a phase I/II trial. J Clin Oncol 6:880-888.

Mintz CD, Dickson TC, Gripp ML, Salton SR, Benson DL (2003) ERMs colocalize transiently with L1 during neocortical axon outgrowth. J Comp Neurol 464:438-448.

Mohrmann R, Lessmann V, Gottmann K (2003) Developmental maturation of synaptic vesicle cycling as a distinctive feature of central glutamatergic synapses. Neuroscience 117:7-18.

Mozhayeva MG, Sara Y, Liu X, Kavalali ET (2002) Development of vesicle pools during maturation of hippocampal synapses. J Neurosci 22:654-665.

Nichols RA, Sihra TS, Czernik AJ, Nairn AC, Greengard P (1990) Calcium/ calmodulin-dependent protein kinase II increases glutamate and noradrenaline release from synaptosomes. Nature 343:647-651.

Nie T, McDonough CB, Huang T, Nguyen PV, Abel T (2007) Genetic disruption of protein kinase $\mathrm{A}$ anchoring reveals a role for compartmentalized kinase signaling in theta-burst long-term potentiation and spatial memory. J Neurosci 27:10278-10288.

Oliveria SF, Dell'Acqua ML, Sather WA (2007) AKAP79/150 anchoring of calcineurin controls neuronal L-type $\mathrm{Ca}^{2+}$ channel activity and nuclear signaling. Neuron 55:261-275.

Papa M, Bundman MC, Greenberger V, Segal M (1995) Morphological analysis of dendritic spine development in primary cultures of hippocampal neurons. J Neurosci 15:1-11. 
Personius KE, Balice-Gordon RJ (2002) Activity-dependent synaptic plasticity: insights from neuromuscular junctions. Neuroscientist 8:414-422.

Phillips LL, Pollack AE, Steward O (1990) Protein synthesis in the neuropil of the rat dentate gyrus during synapse development. J Neurosci Res 26:474-482.

Pratt KG, Watt AJ, Griffith LC, Nelson SB, Turrigiano GG (2003) Activitydependent remodeling of presynaptic inputs by postsynaptic expression of activated CaMKII. Neuron 39:269-281.

Pratt KG, Taft CE, Burbea M, Turrigiano GG (2008) Dynamics underlying synaptic gain between pairs of cortical pyramidal neurons. Dev Neurobiol 68:143-151.

Pyle JL, Kavalali ET, Piedras-Rentería ES, Tsien RW (2000) Rapid reuse of readily releasable pool vesicles at hippocampal synapses. Neuron 28:221-231.

Raff MC, Barres BA, Burne JF, Coles HS, Ishizaki Y, Jacobson MD (1993) Programmed cell death and the control of cell survival: lessons from the nervous system. Science 262:695-700.

Renger JJ, Egles C, Liu G (2001) A developmental switch in neurotransmitter flux enhances synaptic efficacy by affecting AMPA receptor activation. Neuron 29:469-484.

Rizzoli SO, Betz WJ (2004) The structural organization of the readily releasable pool of synaptic vesicles. Science 303:2037-2039.

Rongo C, Kaplan JM (1999) CaMKII regulates the density of central glutamatergic synapses in vivo. Nature 402:195-199.

Rosenmund C, Stevens CF (1996) Definition of the readily releasable pool of vesicles at hippocampal synapses. Neuron 16:1197-1207.

Rosenmund C, Carr DW, Bergeson SE, Nilaver G, Scott JD, Westbrook GL (1994) Anchoring of protein kinase A is required for modulation of AMPA/kainate receptors on hippocampal neurons. Nature 368:853-856.

Ryan TA, Reuter H, Wendland B, Schweizer FE, Tsien RW, Smith SJ (1993) The kinetics of synaptic vesicle recycling measured at single presynaptic boutons. Neuron 11:713-724.

Ryan TA, Li L, Chin LS, Greengard P, Smith SJ (1996) Synaptic vesicle recycling in synapsin I knock-out mice. J Cell Biol 134:1219-1227.

Sabo SL, Gomes RA, McAllister AK (2006) Formation of presynaptic tern nals at predefined sites along axons. J Neurosci 26:10813-1082

Sanes JR, Lichtman JW (2001) Induction, assembly, maturati tenance of a postsynaptic apparatus. Nat Rev Neurosci 2

Schacher S, Wu F (2002) Synapse formation in the ab requires protein synthesis. J Neurosci 22:1831-183

Schworer CM, Colbran RJ, Keefer JR, Soderling I (1988) $\mathrm{Ca}^{2+}$ calmodulin-dependent protein kinase II. Id tification or regulatory autophosphorylation site adjacent to th unhibjory and calmodulinbinding domains. J Biol Chem 263:13486

Semizarov D, Frost L, Sarthy A, Kroeg Halb D , Fesik SW (2003) Specificity of short interfering RN deter nined t, wough gene expression signatures. Proc Natl Acad Sci U 1 o.0J7r 352.

Shen W, Wu B, Zhang Z, Dou Y, Rao ZR, Then YR, Duan S (2006) Activityinduced rapid synaptic maturation med, ed by presynaptic cdc42 signaling. Neuron 50:401-414.

Shi Y, Ethell IM (2006) Integrins control dendritic spine plasticity in hippocampal neurons through NMDA receptor and $\mathrm{Ca}^{2+} /$ calmodulindependent protein kinase II-mediated actin reorganization. J Neurosci 26:1813-1822.

Smith KE, Gibson ES, Dell'Acqua ML (2006) cAMP-dependent protein kinase postsynaptic localization regulated by NMDA receptor activation through translocation of an A-kinase anchoring protein scaffold protein. J Neurosci 26:2391-2402.

Snyder EM, Colledge M, Crozier RA, Chen WS, Scott JD, Bear MF (2005) Role for A kinase-anchoring proteins (AKAPS) in glutamate receptor trafficking and long term synaptic depression. J Biol Chem 280:16962-16968.

Stevens B, Allen NJ, Vazquez LE, Howell GR, Christopherson KS, Nouri N, Micheva KD, Mehalow AK, Huberman AD, Stafford B, Sher A, Litke AM, Lambris JD, Smith SJ, John SW, Barres BA (2007) The classical complement cascade mediates CNS synapse elimination. Cell 131:1164-1178.

Steward O, Schuman EM (2001) Protein synthesis at synaptic sites on dendrites. Annu Rev Neurosci 24:299-325.

Steward O, Worley PF (2001) A cellular mechanism for targeting newly synthesized mRNAs to synaptic sites on dendrites. Proc Natl Acad Sci U S A 98:7062-7068.

Sun J, Bronk P, Liu X, Han W, Südhof TC (2006) Synapsins regulate use- dependent synaptic plasticity in the calyx of Held by a $\mathrm{Ca}^{2+} /$ calmodulindependent pathway. Proc Natl Acad Sci U S A 103:2880-2885.

Sutton MA, Schuman EM (2006) Dendritic protein synthesis, synaptic plasticity, and memory. Cell 127:49-58.

Sutton MA, Wall NR, Aakalu GN, Schuman EM (2004) Regulation of dendritic protein synthesis by miniature synaptic events. Science 304: 1979-1983.

Taylor AM, Berchtold NC, Perreau VM, Tu CH, Li Jeon N, Cotman CW (2009) Axonal mRNA in uninjured and regenerating cortical mammalian axons. J Neurosci 29:4697-4707.

Thiel G, Czernik AJ, Gorelick F, Nairn AC, Greengard P (1988) $\mathrm{Ca}^{2+}$ / calmodulin-dependent protein kinase II: identification of threonine-286 as the autophosphorylation site in the alpha subunit associated with the generation of $\mathrm{Ca}^{2+}$-independent activity. Proc Natl Acad Sci U S A 85:6337-6341.

Tokumitsu H, Inuzuka H, Ishikawa Y, Ikeda M, Saji I, Kobayashi R (2002) STO-609, a specific inhibitor of the $\mathrm{Ca}^{2+} /$ calmodulin-dependent protein kinase kinase. J Biol Chem 277:15813-15818.

van Roessel P, Elliott DA, Robinson IM, Prokop A, Brand AH (2004) Independent regulation of synaptic size and activity by the anaphasepromoting complex. Cell 119:707-718.

Vijayaraghavan S, Goueli S vey MP, Carr DW (1997) Protein kinase A-anchoring inhibit peptide rrest mammalian sperm motility. J Biol Chem 272:4747-

Walsh CA, Morro EM, Ru. enste JL (2008) Autism and brain development. Cell

Wayman GA Kar han WF, Davare M, Impey S, Tokumitsu H, Nozaki N, Ba er G, So rlin TR (2004) Regulation of axonal extension and gre the motily by calmodulin-dependent protein kinase I. J Neuci 24:37 -3794 .

eliky M (2000) Correlated neuronal activity and visual cortical development. feuron 27:427-430.

lleumie K, Pulst SM, Schweizer FE (2006) Proteasome inhibition trigivity-dependent increase in the size of the recycling vesicle pool in altured hippocampal neurons. J Neurosci 26:11333-11341.

Wong W, Scott JD (2004) AKAP signalling complexes: focal points in space and time. Nat Rev Mol Cell Biol 5:959-970.

Wu GY, Malinow R, Cline HT (1996) Maturation of a central glutamatergic synapse. Science 274:972-976.

Wu KY, Hengst U, Cox LJ, Macosko EZ, Jeromin A, Urquhart ER, Jaffrey SR (2005) Local translation of RhoA regulates growth cone collapse. Nature 436:1020-1024.

Yao I, Takagi H, Ageta H, Kahyo T, Sato S, Hatanaka K, Fukuda Y, Chiba T, Morone N, Yuasa S, Inokuchi K, Ohtsuka T, Macgregor GR, Tanaka K, Setou M (2007) SCRAPPER-dependent ubiquitination of active zone protein RIM1 regulates synaptic vesicle release. Cell 130:943-957.

Yao J, Sasaki Y, Wen Z, Bassell GJ, Zheng JQ (2006) An essential role for beta-actin mRNA localization and translation in $\mathrm{Ca}^{2+}$-dependent growth cone guidance. Nat Neurosci 9:1265-1273.

Yashiro K, Riday TT, Condon KH, Roberts AC, Bernardo DR, Prakash R, Weinberg RJ, Ehlers MD, Philpot BD (2009) Ube3a is required for experience-dependent maturation of the neocortex. Nat Neurosci. Advance online publication. Retrieved July 9, 2009. doi: 10.1038/nn.2327.

Yasuda H, Barth AL, Stellwagen D, Malenka RC (2003) A developmental switch in the signaling cascades for LTP induction. Nat Neurosci 6:15-16.

Zhang W, Benson DL (2001) Stages of synapse development defined by dependence on F-actin. J Neurosci 21:5169-5181.

Zhang W, Benson DL (2006) Targeting and clustering citron to synapses. Mol Cell Neurosci 31:26-36.

Zheng J, Buxbaum RE, Heidemann SR (1994) Measurements of growth cone adhesion to culture surfaces by micromanipulation. J Cell Biol 127:2049-2060.

Zhu Y, Stevens CF (2008) Probing synaptic vesicle fusion by altering mechanical properties of the neuronal surface membrane. Proc Natl Acad Sci U S A 105:18018-18022.

Zinck R, Cahill MA, Kracht M, Sachsenmaier C, Hipskind RA, Nordheim A (1995) Protein synthesis inhibitors reveal differential regulation of mitogen-activated protein kinase and stress-activated protein kinase pathways that converge on Elk-1. Mol Cell Biol 15:4930-4938.

Zoghbi HY (2003) Postnatal neurodevelopmental disorders: meeting at the synapse? Science 302:826-830. 